\title{
Requests from the Indies. Asian Agency in the voc's Currency Supply to Eighteenth-Century Java
}

\author{
Alberto Feenstra \\ University of Leiden, Leiden, The Netherlands \\ h.a.feenstra@hum.leidenuniv.nl
}

\begin{abstract}
This paper reconstructs the chain of demand for cash from Asia to the Dutch Republic in the seventeenth and eighteenth centuries. It shows that the Javanese's currency preferences were visible in the exports from Europe. The growing Dutch involvement in Javanese society from the 168 os increased and transformed the composition of the currencies requested from the Dutch Republic, towards more smaller denomination coins. The paper also demonstrates that with regard to the money supply, considerations of state prevailed over purely business interests. The limitations to the Dutch power forced them to adjust to the local power holders their currency preferences.
\end{abstract}

\section{Keywords}

currency - demand-driven money supply - Dutch East India Company - early modern globalization - Indonesia

\section{$1 \quad$ Introduction 1}

The start of modern economic growth in Europe in the eighteenth century coincided with European territorial expansion. This fostered the idea that Europe's

1 The author wishes to thank Ulbe Bosma, Joost Schokkenbroek, Christiaan van Bochove, Remco Raben, the participants in the Wageningen Rural History seminar and the AAS Workshop "New Frontiers in Asian Economic History" in Lansing, Michigan, and the "Multiple payment systems in globalizing economies" workshop in Osaka and session of the same name at the Boston WEHC 2018 and the anonymous referee for their valuable feedback on earlier drafts of this paper. 
economic rise was not only built on but also caused Asia's underdevelopment. ${ }^{2}$ Although the synchronicity of timing of the economic divergence and beginning of colonialism remains remarkable, it is no longer understood to be the case that the Europeans ruined the Asian economies as soon as they arrived. ${ }^{3}$ Instead, various scholars have proposed to move beyond the dichotomy of Europeans versus Asians to enable a fuller understanding of Asian economic history. ${ }^{4}$ This paper examines the isle of Java, where the Dutch founded their Asian headquarters in Batavia, present-day Jakarta, in the early seventeenth century. ${ }^{5}$ Recent publications on early-modern Javanese history fit the general historiographical trend to understand interaction between Europeans and Asians not exclusively as a history of colonial exploitation. Rather than a history of Dutch overpowering the local society, they focus on shared interests between the Dutch and the local elites to explain political and economic processes. ${ }^{6}$ This historiographical

2 A.J.S. Reid, Southeast Asia in the Age of Commerce, 1450-1680 (New Haven, [Conn. etc.]: Yale University Press, 1993), 29o; Reid's concept was recently reinvigorated and for Indonesia almost literally repeated by: Daron Acemoglu and James A. Robinson, Why Nations Fail: The Origins of Power, Prosperity, and Poverty (London etc.: Profile Books, 2012), 247-50; Others have discussed this relation more critically. For the voc most recently and importantly: Pim de Zwart, "Globalization in the Early Modern Era: New Evidence from the Dutch-Asiatic Trade, c. 16oo-180o," The Journal of Economic History 76, no. o2 (June 2016): 520-58; Pim De Zwart and Jan Luiten Van Zanden, "Labor, Wages, and Living Standards in Java, 168o1914," European Review of Economic History, April 1, 2015; Adam Clulow, The Company and the Shogun: The Dutch Encounter with Tokugawa Japan, Columbia Studies in International and Global History (New York: Columbia University Press, 2014); More in general: Victor Lieberman, "Wallerstein's System and the International Context of Early Modern Southeast Asian History," Journal of Asian History, no. 1 (1990): 70; Patrick O’Brien, "Historiographical Traditions and Modern Imperatives for the Restoration of Global History," Journal of Global History 1, (2006): 11; Ulbe Bosma, "Why Europe Grew Rich and Asia Did Not," International Review of Social History (2013): 120.

3 Stephen Broadberry and Pierre van der Eng, "Historical Perspectives on Asian Economic Growth and Development," Explorations in Economic History, no. 3 (2010): 26o-4.

4 Broadberry and Van der Eng; Hui Kian Kwee, The Political Economy of Java's Northeast Coast, c. 1740-180o: Elite Synergy, (Leiden etc.: Brill, 2006); O'Brien, "Historiographical Traditions and Modern Imperatives for the Restoration of Global History"; Giuseppe Marcocci, "Too Much to Rule: States and Empires across the Early Modern World," Journal of Early Modern History 20, 6 (2016): 511-25.Marcocci's study draws interesting parallels between European states and state formation and overseas empires.

5 Femme S. Gaastra, De geschiedenis van de VOC (Zutphen: Walburg Pers, 2007), 40.

6 Ota Atsushi, Changes of Regime and Social Dynamics in West Java: Society, State and the Outer World of Banten, 1750-1830, (Leiden etc.: Brill, 2006); Hui Kian Kwee, "How Strangers Became Kings," Indonesiaand the Malay World 36, no.105(2008):293-307; Kwee, The PoliticalEconomy of Java'sNortheastCoast, c.1740-180o;LucW.Nagtegaal,RijdenopeenHollandseTijger:DeNoordkust van Java En de V.O.C. 1680-1743 (Utrecht: Rijksuniversiteit Utrecht, 1988); Luc W. Nagtegaal, Riding the Dutch Tiger: The Dutch East Indies Company and the Northeast Coast of Java 16801743, trans. Beverley R. Jackson, Verhandelingen van Het Koninklijk Instituut Voor Taal-, Land- En Volkenkunde 171 (Leiden: KITLv Press, 1996); Robert Van Niel, Java's Northe ast 
downplaying of Dutch power requires a revaluation of how the Dutch impacted Java's economic development in the seventeenth and eighteenth centuries. If, as scholars today generally agree, Dutch power was more constrained than previously assumed, then the Dutch East India Company (Verenigde Oostindische Compagnie, hereafter voc) must have employed other or alternative strategies to achieve its political and commercial objectives. Since the voc's impact remains undeniable, the question thus arises: how did the voc affect Java's economy if its political powers remained limited?

As an alternative to force, De Vries has proposed to examine the voc from the perspective of its trade relations, rather than as a proto-imperialistic enterprise. ${ }^{7}$ Following this approach, De Zwart has recently established that the voc's gross margins declined due to competition in areas and for products for which it held no monopoly rights. ${ }^{8}$ The acquisition of goods for the European market thus depended on market conditions. We also know that demand in Asia for European products remained limited and that most of the purchases had to be conducted in cash. ${ }^{9}$ For the voc, the export of cash increased suddenly from 168 os. Moreover, these exports exceeded the increase in the value of the goods shipped back to Europe. This was, according to Gaastra, due to decreased profitability of its Asian operations. Heleaves the question open whether this resulted from shrinking trade margins, expensive bureaucracy or territorial expansion..$^{10}$ It is notable that this coincided with the voc's increasing involvement in the political affairs of Java's main monarchy, Mataram.11

Coast 1740-1840: A Study in Colonial Encroachment and Dominance, (Leiden: CNwS Publications, 2005); Jan Christiaan Nierstrasz, In the Shadow of the Company: The VOC (Dutch East India Company) and Its Servants in the Period of Its Decline (1740-1796) ([s.n.], 2008); Gert J. Oostindie, "Squaring the Circle—Commemorating the voc after 400 Years," Bijdragen Tot de Taal-, Land-En Volkenkunde, no. 1 (2003): 135-62.

7 Jan De Vries, "The Limits of Globalization in the Early Modern World," The Economic History Review, no. 3 (2010): 730-1.

8 de Zwart, "Globalization in the Early Modern Era." passim.

9 F.S. Gaastra, "De Verenigde Oost-Indische Compagnie in de zeventiende en achttiende eeuw: de groei van een bedrijf. Geld tegen goederen. Een structurele verandering in het Nederlands-Aziatisch handelsverkeer," Bijdragen en mededelingen betreffende de geschiedenis der Nederlanden 91, no. 2 (1976): 249-72; Dennis Owen Flynn and Arturo Giraldez, "Cycles of Silver: Global Economic Unity through the Mid-Eighteenth Century," Journal of World History 13, no. 2 (2002): 391-427; Gerrit J. Knaap, "Coffee for Cash," Trading Companies in Asia 1600-1830, HES studies in colonial and non-European history, 3 (1986): 33-49.

10 Gaastra, "Geld tegen goederen," 255-6, 270-1.

11 Kwee, The Political Economy of Java's Northeast Coast, c. 1740-180o, 30; Kwee, "How Strangers Became Kings," 269-301; Nagtegaal, Hollandse Tijger, 17-21; Merle C. Ricklefs, Jogjakarta under Sultan Mangkubumi, 1749-1792: A History of the Division of Java, London Oriental Series, (London, 1974), 20-1, 44; M.C. Ricklefs, War, Culture and Economy in Java, 1677-1726: Asian and European Imperialism in the Early Kartasura Period, Asian Studies 
So, it may well have been the case that said involvement altered its monetary needs, because the Company's political operations increased relative to its commercial ones. The hypothesis of this paper is that the increasing political involvement is reflected in a change in the composition of the sorts of cash requested from the voc's board of directors in Amsterdam.

This paper examines from a monetary perspective how the voc's increasing involvement in Javanese society related to local economic developments. To this end, it first provides an outline of Java's turbulent political environment in which the voc became increasingly involved in the eighteenth century. This overview is necessary in order to relate the growing political involvement to the changes in the composition of the various types of currency requested. The article then reconstructs how monetary needs were communicated within the voc organization, between Asia and Europe. It then proceeds to establish a link between these demands for specific currencies and the voc's demands for Javanese commodities and larger economic developments and to show how the "demand chain" functioned in practice. The paper argues that the voc responded to local populations' specific currency preferences to purchase commodities for its trade, and this response found its way through the organisation in Asia to Amsterdam. This means that economic incentives through the market formed an important means for the company to acquire the desired products. ${ }^{12}$ Their interests were often best served when responding to local demands and preferences, implying agency by the local populace. Changes in the money supply must thus be seen as a symptom of changes in local circumstance and of the European limitations within Asia.

\section{2 The voc's Involvement in Javanese Politics}

Java in the seventeenth and the early eighteen centuries was ravaged by a series of wars and revolts. This period of instability ended with the Peace of Gyanti, concluded in the treaties of 1755 and $1757 \cdot \cdot^{13}$ The voc developed

Association of Australia 24 (London: Allen and Unwin, 1993), 149-51; Merle Calvin Ricklefs, "De Verenigde Oost-Indische Compagnie en de gewelddadige wereld van het vroegmoderne Azië," in: De Verenigde Oost-Indische Compagnie : Tussen Oorlog en Diplomatie, ed. Gerrit J. Knaap and Ger Teitler, Verhandelingen van Het Koninklijk Instituut Voor Taal-, Land- En Volkenkunde 197 (Leiden: KITLV Uitgeverij, 2002), 370.

12 Nierstrasz, In the Shadow of the Company.

13 Kwee, The Political Economy of Java's Northeast Coast, c. 1740-1800, 10; War generally frustrates economic development, as it absorbs people and resources in an unproductive manner and destroys lives and ruins farming land. The Dutch Republic formed the major 
from a marginal actor to a major player between the mid-seventeenth and mid-eighteenth century. The establishment of its headquarters in Batavia in 1618-19 was a violent enterprise that depended on its naval fire power. ${ }^{14}$ The south-central principality of Mataram had recently brought the majority of Java's northeast coast under its control, and its troops besieged Batavia in 1628 and $1629 .{ }^{15}$ Only after the death of the Sultan Agung in 1646 did the voc and Mataram establish friendlier relations. ${ }^{16}$ Some thirty years later, the voc intervened for the first time in Mataram's political affairs, after requests for support from the principality's two leading rival factions. ${ }^{17}$ This intervention proved in the long run to be a watershed in Java's history. ${ }^{18}$

The voc's involvement in Mataram's internal political affairs began in 1676 when both the crown prince and the Madurese prince Trunajaya requested military assistance from the voc..$^{19}$ During the 8o-year period from 1675 to 1755 , Mataram was at peace for just 35 years. The historiography distinguishes the following wars and revolts: the revolt of Trunajaya (1676-168o), the revolt of Surapati (1686-1703), The First War of Javanese Succession (1703-8), The Second War of Javanese Succession (1718-1723), the Chinese revolt (1740-1745), and The Third War of Javanese Succession (1746-1755). ${ }^{20}$ Most of the seventeenth century, the voc struggled with the neighbouring Sultanate of Banten, to its west too. ${ }^{21}$ During that century the voc lacked the power to even protect Batavia's immediate hinterlands, the so-called Surroundings, against attacks from Banten or Mataram. ${ }^{22}$ During the war with Banten that broke out in 1656 , all ten sugar mills in Batavia's Surroundings were destroyed. The peace treaty of

exception to this rule in the early-modern period: Marjolein C. 't Hart, The Dutch Wars of Independence: Warfare and Commerce in the Netherlands 1570-1680, (London: Routledge, 2014), 191.

14 J. van Goor, Jan Pieterszoon Coen, [1587-1629]: koopman-koning in Azië, 2015; Gaastra, Geschiedenis, 40.

15 Kwee, "How Strangers Became Kings," 296.

16 Kwee, The Political Economy of Java's Northeast Coast, c. 1740-1800, 29-30.

17 Nagtegaal, Hollandse Tijger, 17.

18 Gaastra, Geschiedenis, 57; Kwee, The Political Economy of Java's Northeast Coast, c. 1740180o, 30; Nagtegaal, Hollandse Tijger, 17.

19 Nagtegaal, Hollandse Tijger, 19.

20 Kwee, "How Strangers Became Kings," 296-301; Nagtegaal, Hollandse Tijger, 17-21; Ricklefs, Jogjakarta under Sultan Mangkubumi, 20-1, 44; Kwee, The Political Economy of Java's Northeast Coast, c. 1740-1800, 30.

21 Jannes Hendrik Talens, Een Feodale Samenleving in Koloniaal Vaarwater: Staatsvorming, Koloniale Expansie En Economische Onderontwikkeling in Banten, West-Java, 1600-1750 (Hilversum: Verloren, 1999).

22 Elisabeth Maria Jacobs, Koopman in Azië: de handel van de Verenigde Oost-Indische Compagnie tijdens de 18de eeuw (Zutphen: Walburg Pers, 2000), 189. 
1659 with Banten and the subjugation of the sultanate in the 168 os, made the area safer. ${ }^{23}$ With each of the wars, the company's influence grew by acquiring privileges, political say, monopolies, financial compensation for military assistance and territorial gains. ${ }^{24}$ The voc gained influence, by tipping the balance in favour of one or the other of the warring parties-by supplying troops-not by imposing its will as a hegemonic power. ${ }^{25}$

One way for the voc to take advantage of its increased influence in the region was to demand financial compensation for military services. The voc tried to recover at least part of its expenses by transferring debts to the belligerent parties. For instance, after the First Javanese War of Succession, the victorious new monarch, or susuhunan, Pakabuwana I agreed to pay the voc substantial instalments in cash, although in the end he paid just two-thirds of his debt. ${ }^{26}$ Pakabuwana promised to pay up increased Mataram's need for ready cash. This probably reinforced the process of increasing monetisation of taxation, and corresponding decline of statutory labour, that was already underway. ${ }^{27}$ The Mataram state's acceptance of dubbeltjes — a Dutch currency also known as double stivers - as tax payment, from 1703, spurred the the usage of these coins in Java. ${ }^{28}$ Hence, even before the voc taxed Java's inland directly, tax revenues flowed through Mataram's state coffers to the Company, in Dutch currency.

The voc's income from taxes increased from the seventeenth into eighteenth century in both relative and absolute terms. De Vries' observed a jump in taxes during 176 os from $28 \%$ to $45 \%$ of the voc's total income. ${ }^{29}$ These figures are less straightforward than De Vries suggests. First, as can be seen from Table 1, the strong increase in the share of the tax revenue in the total income was due to a fall in the proportion of revenue accruing from trade, not as a result of an increase in tax revenue. Second, changes in 1743 and 1768 in the voc's already

23 Johan Leonard Blussé, Strange Company: Chinese Settlers, Mestizo Women and the Dutch in VOC Batavia ([Leiden]: s.n.], 1986), 23-4; Jacobs, Koopman in Azië, 189-9o: The low lands outside the city walls that extended some zo kilometres inland. Talens, Een Feodale samenleving in koloniaal vaarwater, 95-97, 194-202.

24 Jacobs, Koopman in Azië, 181.

25 Ricklefs, Jogjakarta under Sultan Mangkubumi; Talens, Een Feodale Samenleving in Koloniaal Vaarwater; Atsushi, Changes of Regime and Social Dynamics in West Java; Kwee, "How Strangers Became Kings"; Kwee, The Political Economy of Java's Northeast Coast, c. 1740-180o; Van Niel, Java's Northeast Coast 1740-1840.

26 Ricklefs, War, Culture and Economy in Java, 1677-1726, 154-5.

27 Peter Boomgaard, "Labour, Land, and Capital Markets in Early Modern Southeast Asia from the Fifteenth to the Nineteenth Century," Continuity and Change : A Journal of Social Structure, Law and Demography in Past Societies, no. 1 (2009): 62; Nagtegaal, Hollandse Tijger, 191; Kwee, The Political Economy of Java's Northeast Coast, c. 1740-1800, 104, 114-7, 127.

28 Nagtegaal, Hollandse Tijger, 187.

29 De Vries, "The Limits of Globalization in the Early Modern World," 727. 
complex bookkeeping method may have caused miscalculations; to correct for a different valuation of silver in Asia, the Company in Asia increased the value of currency received from Europe by $25 \%$. The value in Europe was described as 'heavy', the Asian value as 'light'. ${ }^{30}$ It is notable that a jump in total income can be observed in the period 1743-1768, when the accounts were kept in 'heavy' European money, in contrast to the period when it was kept in 'light' Asian money. When expressed in the same currency, as is done in Table 1, the voc's income from taxes can be seen to have increased swiftly from the $168 \mathrm{os}$ onwards and stabilised from around the 1740 .

The voc's power must not be overestimated. In spite of its ambition to achieve peace and tranquillity -war being bad for business - hostilities remained entrenched until 1755. Warfare yielded negative effects in lives lost, trade decline, forgone harvests and the destruction of industrial assets such as sugar mills. ${ }^{31}$ Arguably, the most telling example of the voc's limited powers is the Company's inability to end the Third Javanese War of Succession. Right before his death in 1749, Mataram's monarch Pakubuwana II transferred his sovereignty to the voc. The war nevertheless dragged on, because the voc failed to defeat the rebels. Instead of reuniting the empire under Pakubuwana III, the Company had to allow Mataram's tri-partition in 1755 and 1757 among three rulers. Soon, the division of power proved more effective and less costly than the hitherto pursued policy of military intervention in support of a single pretender to the throne. ${ }^{32}$ Meanwhile, peace brought demographic and economic growth. ${ }^{33}$

30 J.P. de Korte, De Jaarlijkse Financiële Verantwoording in de VOC, Verenigde Oostindische Compagnie, Werken, Uitgegeven Door de Vereeniging Het Nederlandsch EconomischHistorisch Archief 17 (Leiden: Nijhoff, 1984), 32-3, 39-40, 47, 49; Willem G. Wolters, "Heavy and light money in the Netherlands Indies and the Dutch Republic," Financial History Review, no. 1 (2008): 37-54; Gaastra, Geschiedenis, 144-6.

31 Ricklefs, War, Culture and Economy in Java, 1677-1726, 149-51.

32 Ricklefs, "De V.O.C. En de Gewelddadige Wereld," 370.

33 This relatively peaceful period lasted until the Java War (1825-1830): Peter Boomgaard, "Morbidity and Mortality in Java, 1820-188o: Changing Patterns of Disease and Death," in Death and Disease in Southeast Asia: Explorations in Social, Medical and Demographic History, ed. Norman G. Owen, Southeast Asia Publications Series / Asian Studies Association of Australia 14 (Singapore etc.: Oxford University Press, 1987), 50; Peter Boomgaard and A.J. Gooszen, Population Trends 1795-1942, Changing Economy in Indonesia 11 (Amsterdam: Royal Tropical Institute (KIT), 1991), 82; Alberto Feenstra, "Dutch Coins for Asian Growth. voc-Duiten to Assess Java's Deep Monetisation and Economic Growth, 1724-180o," Tijdschrift Voor Sociale En Economische Geschiedenis 11, no. 3 (2014): 123-54: In the century before 1755, Java's population had declined, to around 4.5 million, and then increased to approximately 7.5 million in 180o; Jacobs, Koopman in Azië, 183; Nagtegaal, Hollandse Tijger, 191; Robert Van Niel, "Economic and Population Changes in Java, 1750-185o," in Economic and Demographic Development in Rice Producing Societies: Some Aspects of East Asian Economic History, 1500-19oo, ed. Yoshihiro Tsubouchi Yoshihiro and Hayami Akira (Tokyo / Leuven: Leuven University Press, 199o), 122-3; Anthony J.S. Reid, 
TABLE 1 Composition of VOC revenue in Asia, 1640-179o (in ducatoons of 66 stivers)

\begin{tabular}{|c|c|c|c|c|c|}
\hline & $\begin{array}{l}\text { Trade } \\
\text { revenue } \\
\text { per year }\end{array}$ & $\begin{array}{l}\text { Tax income } \\
\text { per year }\end{array}$ & $\begin{array}{l}\text { Other } \\
\text { income } \\
\text { per year }\end{array}$ & $\begin{array}{l}\text { Total income } \\
\text { per year }\end{array}$ & $\begin{array}{l}\text { Original currency } \\
\text { in bookkeeping }\end{array}$ \\
\hline $1640-165^{\circ}$ & $2,232,209$ & 209,635 & 62,365 & $2,504,208$ & 'light' money \\
\hline $1650-166 o$ & $2,433,843$ & 175,168 & 61,020 & $2,670,031$ & 'light' money \\
\hline 166o-1669 & $3,731,336$ & $242,45^{\circ}$ & $-53,981$ & $3,919,8 \circ 5$ & 'light' money \\
\hline $1669-1681$ & $3,316,471$ & 281,935 & 17,147 & $3,615,554$ & 'light' money \\
\hline $1681-1689$ & $3,664,284$ & 372,343 & 7,040 & $4,043,667$ & 'light' money \\
\hline $1689-1692$ & $3,461,726$ & 596,624 & 699,173 & $4,757,5^{23}$ & 'light' money \\
\hline 1692-1700 & $3,412,272$ & 869,543 & 71,442 & $4,353,257$ & 'light' money \\
\hline $1700-1710$ & $2,805,421$ & 885,833 & 12,768 & $3,704,08 \circ$ & 'light' money \\
\hline $1710-1721$ & $3,002,046$ & $1,104,187$ & 8,168 & $4,114,462$ & 'light' money \\
\hline $1721-1730$ & $2,856,038$ & $1,287,05^{\circ}$ & 23,895 & $4,167,041$ & 'light' money \\
\hline $1730-1740$ & $3,020,937$ & $1,482,226$ & $30,5^{13}$ & $4,533,737$ & light' money \\
\hline $1740-1743$ & $3,999,542$ & 858,661 & 23,535 & $4,881,819$ & 'light' money \\
\hline $1743^{-175^{\circ}}$ & $5,124,468$ & $2,075,645$ & 81,464 & $7,281,578$ & 'heavy' money \\
\hline $175^{\circ-176 \circ}$ & $5,242,254$ & $1,966,5 \circ 6$ & $5^{\circ}, 724$ & $7,259,484$ & 'heavy' money \\
\hline $1760-1768$ & $3,799,019$ & $2,137,443$ & 39,391 & $5,975,853$ & 'heavy' money \\
\hline $1768-1780$ & $2,577,476$ & $2,171,793$ & 120,956 & $4,870,225$ & ducatoons \\
\hline $1780-179 \circ$ & $2,768,0 \circ 3$ & $2,155,259$ & 74,613 & $4,997,875$ & ducatoons \\
\hline
\end{tabular}

SOURCE: DE KORTE, FINANCIËLE VERANTWOORDING, PP. 31, 39-40, 47, 49

However, as late as 1780 the voc still depended on Javanese military assistance to maintain its defences against the British, as part of the Fourth Anglo-Dutch War (1780-1784). ${ }^{34}$ Hence, internal turmoil allowed the voc to increase its

"Low Population Growth and Its Causes in Pre-Colonial Southeast Asia," in Death and Disease in Southeast Asia: Explorations in Social, Medical and Demographic History, ed. Norman G. Owen, Southeast Asia Publications Series / Asian Studies Association of Australia 14 (Singapore etc.: Oxford University Press, 1987), 35, 46; Merle Calvin Ricklefs, "Some Statistical Evidence on Javanese Social, Economic and Demographic History in the Later Seventeenth and Eighteenth Centuries," Modern Asian Studies 20 (1986): 30; De Zwart and Van Zanden, "Labor."

34 Kwee, "How Strangers Became Kings," 300, 304; Van Niel, Java's Northeast Coast 1740-1840, 48; Remco Raben, "Round about Batavia: Ethnicity and Authority in the Ommelanden, 1650-180o," in Jakarta-Batavia: Socio-Cultural Essays, ed. Kees Grijns and Petrus Jacobus Maria Nas, Verhandelingen van Het Koninklijk Instituut Voor Taal-, Land- En Volkenkunde 187 (Leiden: KITLV Press, 200o), 93-113: Raben described the voc's control over Batavia's Surroundings [Dutch: Ommelanden van Batavia] as "very fragile." 
political control over Java, of which the voc officials took advantage as soon as they saw the opportunity to do so. ${ }^{35}$ This changing role of the voc, from trader to territorial ruler, is reflected in the composition of its income.

Others have already linked the voc's supply of currency in Java to its increasing political involvement. Nagtegaal linked this to the introduction of dubbeltjes in the 168os and the acceptance of the currency as tax payment from 1703. Kwee argued that the presence of duiten enabled monetised taxation from the 176 os onwards. ${ }^{36}$ In the period between 1720 and 1760 , duiten had become the standard means of payment and consequently the most easily obtained money through taxation. Whereas the success of the dubbeltjes was related to the interaction between the state of Mataram and the voc, the success of the duiten depended on the acceptance by and preference of the ordinary Javanese as will be discussed in section 4 .

\section{3}

\section{Demand and Supply within the voc}

Since the voc was politically far from omnipotent, it had to adjust to local circumstances. This also holds for its economic position in Java. It could not set prices and determine quantities of goods as it did in the Moluccas and Ceylon. ${ }^{37}$ In Java the Company had to consider market circumstances, including supply and demand. If the Company deemed it necessary, it turned to coercion to obtain the desired goods on its own terms. Yet it could not do so everywhere or all the time; Java's northeast coast was simply too large for the voc to exercise continuous control over the commodity flows. The company employed only a few thousand Company servants in Java, against a total of about 5 million Javanese. ${ }^{38}$ Even if the voc had considered exercising permanent control, this would have been an extremely costly option. Adapting to the market was both cheaper and easier. The adaptation to the market implied that the voc had to pay in currencies that the local counterparties accepted. This section analyses how the Company responded to monetary demands and currency preferences, by examining the correspondence about monetary requirements within the voc organisation between Amsterdam and Batavia.

My hypothesis is that the voc adapted its shipments of money to local currency preferences. The correspondence within the voc organisation

\footnotetext{
35 Kwee, The Political Economy of Java's Northeast Coast, c. 1740-1800.

36 Kwee, 112-8, 125 .

37 de Zwart, "Globalization in the Early Modern Era", 536-8.

38 Gaastra, Geschiedenis, 85-87: in the 1680s the voc employed 4,0oo officials in Java; in 1700, 5,ooo; in 1753 about 8,ooo; and in 1780, 5,ooo; Feenstra, "Dutch Coins," 168.
} 
provides us with clues to test this hypothesis with with regard to practices in eighteenth-century Java. This section first provides an overview of the exports from the Dutch Republic to Asia over the entire period of the voc's existence. It proceeds then to examine how the voc administration in Batavia - the High Government-formulated its requests to the board of directors in Amsterdam, the 'Gentlemen XVII. ${ }^{39}$ It then describes how local demand for specific currencies informed the drafting of the requests in Batavia. Finally, it discusses how the board in Amsterdam responded. Establishing a clear link between demand and supply is important because the figures about the actual exports are well preserved, while our information about the requested monetary supply is obscure. ${ }^{40}$ Hence, understanding how the board in Amsterdam assessed the demands from Asia improves our understanding of the representativeness of the supply for gauging Asian demand.

\subsection{The Exports to India}

Figure 1 represents the total shipments of money exported from the Dutch Republic to Asia, throughout the voc's existence. The figure shows a significant change around 1680. Until then, the value of the exported money and bullion hovered around 10 million guilders per decade. Thereafter, this amount increased, up to 60 million guilders in the 1720 s. Although this latter figure was an outlier, and the value of shipments thereafter declined, it nevertheless remained substantially higher than than anything seen in the 17th century, at between 40 and 50 million guilders per annum. The increase in money shipped from the Dutch Republic to Asia coincided with what we have seen above was the company's increased involvement in Javanese political affairs.

In Figure 1, I distinguish between bullion and large currency, on the one hand, and small change, on the other ${ }^{41}$ Until the 1640 , the voc shipped no small currency to Asia at all. As noted above, the demand for dubbeltjes increased from the 168os. This increase was indicative of a larger change: during the same period, exports of bullion and small-denomination coinage increased also. From the 168 os to 1720 s exports of small currency also increased as a percentage of total exports. The amounts in this period equalled those of the total exports in the period up until then. The increased of smaller currencies is

39 This High Government consisted of the Governor-General and the Council of the Indies.

40 J.R. Bruijn, F.S. Gaastra, and I. Schöffer, eds., Dutch-Asiatic Shipping in the 17th and 18th Centuries. Vol. I: Introductory Volume, Rijks Geschiedkundige Publicatiën : Grote Serie 165 (The Hague: Nijhoff, 1987); Arent Pol, "Tot Gerieff van India. Geldexport Door de voc En de Muntproduktie in Nederland, 1720-1740," Jaarboek Voor Munt-En Penningkunde 72 (1985): 69.

41 For the purposes of this paper, I regard every unit of currency less than 1 guilder 'small', and everything else 'large'. 


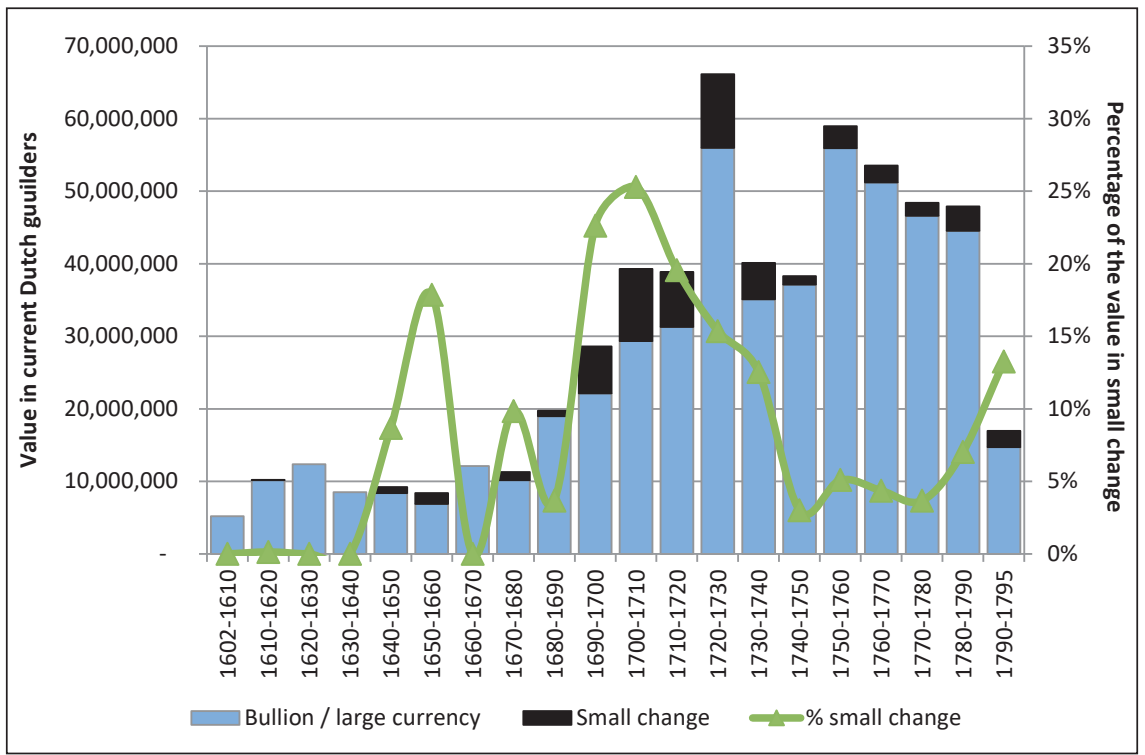

FIGURE 1 Money shipment from the Dutch Republic to Asia, 1602-1795 SOURCE: BRUIJN, GAASTRA, AND SCHÖFFER, DAS, I: INTRODUCTORY VOLUME: PP. 223-269

relevant because the money and bullion served different purposes; bullion and large silver and gold coins sufficed to purchase goods for the Company's wholesale trade, whereas the import of small silver coins and copper coins facilitated everyday transactions. ${ }^{42}$ Hence, the composition of the exports changed from the 168 os, with more money suitable for small daily transactions.

\subsection{Requests from the Indies}

One source that may help us answer this question is the Eisch van Indië (Requests from the Indies). These were lists in which the High Government annually formulated the expected need for supplies, troops, money and bullion in the two years to come. The two-year time lag in the forecast was the result of the long journey—eight to nine months—-from Batavia to Amsterdam and

42 Jan Lucassen, "Introduction: Wages and Currency, 50о BCE-200o CE," in Wages and Currency: Global Comparisons from Antiquity to the Twentieth Century, ed. Jan Lucassen, International and Comparative Social History 10 (Bern etc.: Lang, 2007), 51; Nederlandsch-Indisch Plakaatboek, 1602-1811. Vol. 4: 1709-1743, vol. 4: 1709-1743 (Batavia: Landsdrukkerij 's Hage: Nijhoff, 1887), 185-6. 
TABLE 2 Requested and exported money and bullion over 1779

\begin{tabular}{|c|c|c|c|c|c|}
\hline $\begin{array}{l}\text { Bullion / coin } \\
\text { type }\end{array}$ & $\begin{array}{l}\text { Requested } \\
\text { amount } \\
\text { (In guilders' } \\
\text { worth) }\end{array}$ & & $\begin{array}{l}\text { Bullion / coin } \\
\text { type }\end{array}$ & $\begin{array}{l}\text { Amount } \\
\text { exported from } \\
\text { the Republic } \\
\text { (in guilders' } \\
\text { worth) }\end{array}$ & $\begin{array}{l}\text { Level of } \\
\text { similarity }\end{array}$ \\
\hline Gold bars & 800,000 & & Gold bars & $1,400,000$ & $175 \%$ \\
\hline Re-edged Ducats & $15^{\circ}, 000$ & & Gold Ducats & 150,000 & $100 \%$ \\
\hline $\begin{array}{l}\text { Silver bars ( } 11 \\
\text { pennies, } 20 \text { grains } \\
\text { fineness) }\end{array}$ & 1,6oo,o०o & & Silver bars & $2,600,000$ & $163 \%$ \\
\hline Reals & 1,০০০,০০০ & & $\begin{array}{l}\text { (mark) Reals } \\
\text { New Spanish Reals }\end{array}$ & $\begin{array}{l}1,794,000 \\
1,200,000\end{array}$ & $299 \%$ \\
\hline Ducatoons & 50,000 & & $\begin{array}{l}\text { Ducatoons } \\
\text { Half ducatoons }\end{array}$ & $\begin{array}{l}400,000 \\
200,000\end{array}$ & $\begin{array}{l}800 \% \\
n / a\end{array}$ \\
\hline $\begin{array}{l}\text { "paijement" / small } \\
\text { change }\end{array}$ & 100,000 & \{ & Shillings & $5^{\circ, 000}$ & $150 \%$ \\
\hline & & & $\begin{array}{l}\text { Double stivers } \\
\text { (dubbeltjes) }\end{array}$ & 100,000 & \\
\hline Duiten & 100,000 & & Duiten & 100,000 & $100 \%$ \\
\hline Total & $3,800,000$ & & Total & 7,994,0о० & $210 \%$ \\
\hline
\end{tabular}

SOURCE: NATiONAL ARCHIVE, THE HAgUE (NA), VOC ARCHIVES (VOC), INV.NR. 3471, F. 169, BRUIJN, GAASTRA, EN SCHÖFFER, DAS, I: INTRODUCTORY VOLUME: 223-246

back. The issues of the Eisch van Indië are generally understood to be lost. ${ }^{43}$ But at least two of them have survived, for the years 1779 and 1781 . These documents allow for a comparison between the requested amounts of currencies and the money and bullion actually exported from the Dutch Republic, to gain some insight allowing us to establish the extent to which the High Government's requests were met.

The first observation we can make is that the voc in the Dutch Republic complied at least with all requested denominations, none exempted. The striking point to note is that the total sum exported was more than twice

43 Femme Simon Gaastra, Particuliere geldstromen binnen het VOC-bedrijf 1640-1795, Van Gelder-lezingen 1 (Leiden: Rijksmuseum Het Koninklijk Penningkabinet, 2002); Pol, "Tot Gerieff van India," 69. 
the requested amount. Almost all types of bullion and coins were in quantities larger than requested, though not in equal proportions. While gold ducats and duiten were shipped in the requested quantities, 200,00o guilders' worth of half ducatoons were also shipped, despite none having been requested at all. Gold and silver bars and Reals contributed the most to the excess of the export value in absolute terms, which together amounted to almost 3.6 million more than requested. In relative worth between requested and shipped amount the ducatoons stand out; eight times as much as requested was sent over. On top of that were 200,000 guilders' worth in half ducatoons that had not been requested at all. The Gentlemen XVII thus sent more than met Batavia's High Government's request, mostly in the higher denominations.

Similar observations can be made about money exported in response to the request from 1781. Again the total value of the exports exceeded the requested sum, although not to the same extent as in 1779 . Excesses are again to be found in the categories of gold bars and Reals. All other types of coins and bullion were exported exactly according to the request. The 'Gentlemen XVII' in Amsterdam thus complied completely with all requested sums from Asia.

In both instances the voc in the Republic sent more money to Asia than was requested by the High Government in Batavia. Particularly gold and silver bars and large silver coins contributed to this excess. Smaller silver coins and copper duiten were sent over, according to the request, but not in excess. In both instances, the Voc in the Republic at least complied with the requested amounts for all individual denominations. This level of similarity suggests that the Gentlemen XVII took the Requests seriously and acted accordingly.

Besides these two surviving Requests from the Indies, there is a third source that supports the interpretataion that the voc accurately responded to the Requests from the Indies. In an internal memo from 1785 the Company's cashier Temmick discussed the price, production and production costs of duiten by the provincial mint masters. He wrote the memo because he suspected that the mint masters earned a considerable margin from the minting of the duiten for the voc. Lowering the margin would be possible, he wrote, but this should not come at the expense of the quality or copper content. He indicated that the coins circulated among the "small communities" in Java and Ceylon. Offering poor-quality duiten would reduce the demand for this currency among the Javanese and Ceylonese populations: this would disadvantage the voc, which earned a considerable margin on the issue of the coins. ${ }^{44}$ So, he suggested that 
TABLE 3 Requested and Exported money and bullion over 1781.

\begin{tabular}{|c|c|c|c|c|}
\hline $\begin{array}{l}\text { Bullion / coin } \\
\text { type }\end{array}$ & $\begin{array}{l}\text { Requested } \\
\text { amount } \\
\text { (In guilders' } \\
\text { worth) }\end{array}$ & $\begin{array}{l}\text { Bullion / coin } \\
\text { type }\end{array}$ & $\begin{array}{l}\text { Amount } \\
\text { exported from } \\
\text { the Republic } \\
\text { (In guilders' } \\
\text { worth) }\end{array}$ & $\begin{array}{l}\text { Level of } \\
\text { similarity }\end{array}$ \\
\hline Gold bars & 800,000 & Gold bars & $1,400,000$ & $175 \%$ \\
\hline Gold Ducats & $15^{\circ}, 000$ & Gold Ducats & 150,000 & $100 \%$ \\
\hline $\begin{array}{l}\text { Silver bars ( } 11 \\
\text { pennies, } 20 \text { grains } \\
\text { fineness) }\end{array}$ & 2,०००,००० & Silver bars & 2,०००,००० & $100 \%$ \\
\hline Spanish Reals & 900,000 & $\begin{array}{l}\text { (mark) Reals } \\
\text { New Spanish Reals }\end{array}$ & $\begin{array}{l}1,202,500 \\
900,000\end{array}$ & $234 \%$ \\
\hline Ducatoons & 600,000 & Ducatoons & 600,000 & $100 \%$ \\
\hline Half ducatoons & 200,000 & Half ducatoons & 200,000 & $100 \%$ \\
\hline Shillings & $5^{\circ}, 000$ & Shillings & $5^{\circ}, 000$ & $100 \%$ \\
\hline $\begin{array}{l}\text { Double stivers } \\
\text { (dubbeltjes) }\end{array}$ & 100,000 & $\begin{array}{l}\text { Double stivers } \\
\text { (dubbeltjes) }\end{array}$ & 100,000 & $100 \%$ \\
\hline Duiten & 100,000 & Duiten & 100,000 & $100 \%$ \\
\hline Total & 4,900,00० & Total & $6,702,500$ & $137 \%$ \\
\hline
\end{tabular}

SOURCE: NA, VOC, INV.NR. 3530, F. 163-164, BRUIJN, GAASTRA, EN SCHÖFFER, DAS, I: INTRODUCTORY VOLUME:223-246.

the demand for the duiten from the ordinary Javanese and Ceylonese would drop as soon as the quality of the currency deteriorated.

Table 4 shows that, except for in 1775 , the provincial mints produced coins in the approximate quantities requested. Later in the text Temminck mentioned that for three years no duiten had been requested, whereas the table only indicated this for the years 1773 and 1774. This suggests that also in 1775 a lack of demand explains the absence of exported duiten. ${ }^{45}$ Concerning 1779 , the figures from Table 2 and Table 4 consistently report the requested sum and actual export of 100,00o guilders' worth of duiten. With the exception of 1777 and 1778 , the mint masters produced coinage in the eaxact quantities requested

45 NA, vOC, Inv.nr. 4717, p. 3-4. 
TABLE 4 Requested, produced and exported duiten, 1771-1780.

The company sent duiten to East India over the following years:

\begin{tabular}{|c|c|c|c|c|c|}
\hline \multirow{2}{*}{$\begin{array}{l}\text { Year } \\
1771\end{array}$} & \multicolumn{2}{|c|}{ Requested from the Indies } & \multicolumn{2}{|l|}{ Distributed } & \multirow{2}{*}{$\begin{array}{l}\text { Similarity } \\
100 \%\end{array}$} \\
\hline & f & 100,000 & & 100,000 & \\
\hline 1772 & f & 100,000 & & 100,000 & $100 \%$ \\
\hline 1773 & & nothing & & - & $\mathrm{n} / \mathrm{a}$ \\
\hline 1774 & & nothing & & - & $\mathrm{n} / \mathrm{a}$ \\
\hline 1775 & f & 100,000 & not distributed & & ०\% \\
\hline \multirow[t]{2}{*}{1776} & f & 100,000 & permitted & 70,000 & \} $100 \%$ \\
\hline & & & still $(n \circ g)$ & 30,000 & \\
\hline 1777 & $f$ & 100,000 & & 76,000 & $76 \%$ \\
\hline 1778 & f & 100,000 & & 75,000 & $75 \%$ \\
\hline 1779 & f & 100,000 & & 100,000 & $100 \%$ \\
\hline 1780 & $f$ & 100,000 & & 100,000 & $100 \%$ \\
\hline $1771-1780$ & f & 800,000 & & 651,000 & $81 \%$ \\
\hline
\end{tabular}

SOURCE: NA, VOC, INV.NR. 4717 , P. $2 .{ }^{46}$

by Batavia's High Government. This source confirms that at least in the case of duiten coins were produced according to the Requests of the Indies.

Together, this memo and the two Requests from the Indies are merely three observations in a limited time period. This raises the question how representative this period was and how the High Government drew up the requests in all other years. In the next section of the paper, we will address this question by analysing other internal correspondence of the voc in Java.

\subsubsection{Drawing up the Request in Batavia}

The simultaneous shipment of money to pay for the Company's trade, and smaller denominations to smooth local payments reflects the voc's dual role

46 The terms or desiginations were not entirely clear. I interpreted the designations as follows. Those descibed as 'Distributed', I understood as being minted and sent to Asia; those designated as 'not distributed' (Dutch: 'niet verdeeld') as not minted and thus not exported; 'permitted' (Dutch:'toegestaan') as indication that these have been ordered to be minted, but not the orders not yet having excuted by of the various pronvicial minting houses; those described as 'still' (Dutch:'nog') probably added later to the orders. 
as merchant company and sovereign. At its creation, in 16o2, the voc obtained sovereign powers, including the right to hire soldiers, wage war and conclude treaties as part of its charter as monopolistic company for the trade with Asia. ${ }^{47}$ This corporate dualism formed a source of contention because military actions and expanding administrative control put pressure on profits; ${ }^{48}$ for instance, despite the directors' objections to territorial expansion, the territories under direct control of the Company steadily increased in Java. ${ }^{49}$ The distance in time and miles limited the control of the Amsterdam board over Asian affairs. This fostered an independent course by voc servants in Asia, related to local circumstances. ${ }^{50}$

With the voc's territorial expansion, the administrative duties towards the subjects under its control increased as well. Among these the responsibilities was the need to maintain a sound money supply and an orderly circulation. ${ }^{51}$ The voc servants considered the local tin-lead pici-coins unsound, because their inferior quality caused an extremely high wear rate. ${ }^{52}$ Even before the introduction of the Dutch copper duiten in the 1720s, the voc had attempted to supply sufficient durable coins to Java. In the early eighteenth century, the local voc officials specifically stated that they purposely imported copper coins from Japan because this money was used at Batavia's local market. ${ }^{53}$ The Company could not just issue coins at its own discretion; it had to consider the local needs. For instance in 1711, the Company's officials in Batavia wrote to the Gentlemen XVII that there was no need for copper duiten, because a sufficient number of local copper coins circulated. ${ }^{54}$ This changed a decade later, when the first duiten were sent to Java with the explicitly stated intention of

47 Gaastra, Geschiedenis, 21-22.

48 Oscar Gelderblom, Abe de Jong, and Joost Jonker, "The Formative Years of the Modern Corporation: The Dutch East India Company voc, 1602-1623," The Journal of Economic History 73, no. 4 (December 2013): 1056-8; During the Second War of Javanese Succession the voc's expenditures were 10 times as high as the revenues from Java's northeast coast: Ricklefs, War, Culture and Economy in Java, 1677-1726, 202.

49 Gaastra, Geschiedenis, 56-7; Kwee, The Political Economy of Java's Northeast Coast, $c$. 1740-1800.

$5^{\circ}$ Gaastra, Geschiedenis, 57, 114; Kwee, The Political Economy of Java's Northeast Coast, c. $1740-1800$.

$51 \quad$ Wolters, "Heavy and Light money in the Netherlands Indies and the Dutch Republic," 43.

$5^{2}$ Blussé, Strange Company, 44-45; Feenstra, "Dutch Coins", 172, 176."

53 Generale Missiven van Gouverneurs-Generaal En Raden Aan Heren XVII Der Verenigde Oostindische Compagnie, vol. VII 1713-1725, Rijks Geschiedkundige Publicatiën : Grote Serie 164 ('s-Gravenhage: Nijhoff, 1979), 598.

54 Generale Missiven van Gouverneurs-Generaal En Raden Aan Heren XVII Der Verenigde Oostindische Compagnie, vol. vi 1698-1713, Rijks Geschiedkundige Publicatiën : Grote Serie 159 ('s-Gravenhage: Nijhoff, 1976), 8०5. 
increasing the convenience of people's daily purchases on the market. ${ }^{55}$ Thus, the Requests from the Indies expressed local currency preferences.

Indeed, in their requests to Amsterdam, the voc officials in Asia often referred to the local situation to substantiate their requests. An accompanying letter concerning the 1731 request states that Voc officials were hamstrung by a lack of gold and silver bars: in East Java they had to rely on ducats, rupias and Japanese kobans, whereas the voc bought gold from the Chinese, which they paid for with fractional coins. Yet they immediately requested fractional coins for East Java and Batavia, because it was impossible to obtain them locally. Even more intriguing is that the Javanese converted ducats into smaller coins, which shows a certain preference for fractional coins. voc officials argued that although ducats were more profitable than fractional coins, the Javanese preference was the only reason to request shillings and dubbeltjes - also known as double stivers - from Amsterdam. ${ }^{56}$ This Javanese preference was reflected in the request to the Republic; the demand for 100,000 guilders' worth of duiten was supported by the argument that the total sum and the request for silver fractional coins [Dutch: payement] could now be decreased. ${ }^{57}$ By 1739 the demand for payement in Java had risen again, this time to the level that it was possible to exchange these coins only at a 10 percent premium. ${ }^{58}$ Hence, local needs to uphold a sound money supply translated into the voc's request for certain types of currency, sometimes at the expense of more profitable currencies.

The voc did not merely observe the local situation passively, but tried to promote use by the Javanese of of Dutch coins, for instance the new duitencoins during the early 173 os. Yet the local princes sought to protect their own income derived from the issuance of the tin-lead pici-coins. ${ }^{59}$ Hence, the voc faced competition in the issuance of currencies. The voc had an important incentive to promote the use of its own copper currency, because the exchange rate was highly favourable compared to silver in Europe. ${ }^{60}$ Consequently, the sale of the copper coins was a potentially lucrative business for the voc.

\footnotetext{
55 Bruijn, Gaastra, and Schöffer, DAS, I: Introductory volume:225-46; Plakaatboek 4, 4: 1709-1743:176-8.

56 Generale Missiven van Gouverneurs-Generaal en Raden aan Heren XVII Der Verenigde Oostindische Compagnie, vol. IX 1729-1737, Rijks Geschiedkundige Publicatiën: Grote Serie 205 ('s-Gravenhage: Nijhoff, 1988), 250, 285 .

57 G.M., IX 1729-1737:245.

58 Plakaatboek 4, 4: 1709-1743:537.

59 G.M., 1988, IX 1729-1737:245.

6o Feenstra, "Dutch Coins," 157.
} 
The voc's intrusive promotion seems to have been successful, because in 1732 the initial request for duiten was doubled from 50,000 guilders to 100,000 guilders' worth, due to the scarcity of small change in East Java. ${ }^{61}$ Some twenty years later, it was still hard for the Company's employees to have the voc coins accepted within the local economies. The Batavia administrators urged the local voc officials in $175^{2}$ to promote the use of the Dutch coins with more effort. ${ }^{62}$ By 1755 , the silver Spanish Reals were a still generally accepted means of exchange in Java's interior. The voc's officials wished to change that so that the Javanese should "unnoticed and gently" be deterred in favour of the Dutch coins. ${ }^{63}$ The eventual popularity of the voc's smaller coins can also be illustrated from the repeated bans of counterfeiting later in the period. ${ }^{64}$ The voc could not simply issue the duiten, but had to deal with local competition and willingness to get the voc coins accepted, at which it seems to have been rather successful.

This success was far from preordained, as we can see from what happened in the Maluku island of Ternate. There the introduction of the halve duiten coins in 1756 failed, and the local voc officials requested dubbeltjes, shillings and whole duiten from Batavia instead. ${ }^{65}$ This serves to highlight not only the voc's dependence on local acceptance, but also demonstrates that Batavia's requests to Amsterdam were based on the subordinate trading posts' requests that reflected the demand elsewhere in Asia.

That the demand from the subordinate trading posts formed the basis of the total Request from the Indies can, for instance, been seen in a letter to the board in Amsterdam in 1741. There the High Government stated that the money received from Europe was barely sufficient to cover the trading posts' requests. ${ }^{66}$ This layered practice made projections for the required money

\footnotetext{
$61 \quad$ G.M., 1988, IX 1729-1737:320.

62 Nederlandsch-Indisch Plakaatboek, 1602-1811. Vol. 6: 1750-1754, vol. 6: 1750-1754 (Batavia: Landsdrukkerij 's Hage: Nijhoff, 1889), 194.

63 Nederlandsch-Indisch Plakaatboek, 1602-1811. Vol. 7: 1755-1764, vol. 7: 1755-1764 (Batavia: Landsdrukkerij 's Hage: Nijhoff, 189o), 55-6.

64 Nederlandsch-Indisch Plakaatboek, 1602-1811. Vol. 12: 1795-1799, vol. 12: 1795-1799 (Batavia: Landsdrukkerij 's Hage: Nijhoff, 1894), 459, 936; Nederlandsch-Indisch Plakaatboek, 16021811. Vol. 13: 1800-1803, vol. 13: 1800-1803 (Batavia: Landsdrukkerij 's Hage: Nijhoff, 1895), 19; Nederlandsch-Indisch Plakaatboek, 1602-1811. Vol. 14: 1804-1808, vol. 14: 1804-1808 (Batavia: Landsdrukkerij 's Hage: Nijhoff, 1895), 178.

65 Generale Missiven van Gouverneurs-Generaal En Raden Aan Heren XVII Der Verenigde Oostindische Compagnie, vol. XIII 1756-1761, Rijks Geschiedkundige Publicatiën : Grote Serie $25^{8}$ (Den Haag: Instituut voor Nederlandse Geschiedenis, 2007), 25.

66 Generale Missiven van Gouverneurs-Generaal En Raden Aan Heren XVII Der Verenigde Oostindische Compagnie, vol. x 1737-1743, Rijks Geschiedkundige Publicatiën : Grote Serie 250 (Den Haag: Instituut voor Nederlandse Geschiedenis, 2004), 745.
} 
supply difficult, since not only the time between Europe and Asia had to be taken into account, but also between Batavia and its subordinate trading posts. The High Government in Batavia found itself in a delicate balancing act to supply sufficient money to the subordinate trading posts in Asia, each depending on different local currency preferences, whereas the total supply from Europe was hardly sufficient.

Requests like the one from Ternate, became more detailed after 1750, when a detailed new entry info force. This required the trading posts to provide the following in a separate memorandum, in addition to their requirement of money: (1) a statement of the amounts remaining at the each trading post and their dependencies; (2) the received annual supply of merchandise and provisions; (3) the annual profits and income, by estimate; (4) the debts; (5) the annual expenses, by estimate; (6) the returned goods over the previous year and the current stock; (7) what is needed, in balance. ${ }^{67}$ The purpose of this $175^{\circ}$ instruction was to improve the assessment of what each of the trading posts needed.

\subsubsection{The Pivotal Role of the Grand Money Chamber}

Central to the management of these requests was the Grote Geldkamer [Grand Money Chamber] in Batavia, which physically stored the voc's money in Asia. ${ }^{68}$ The money stock fluctuated due to receipts from the Dutch Republic, re-exports to subordinate trading posts, local issues of currency, wholesale purchases and bills of exchange to be drawn in the Dutch Republic. Personnel and private persons who wanted to transfer money from Batavia to Amsterdam could purchase a bill of exchange. The cash paid for this bill of exchange was handed over to the Money Chamber, so that the money remained in Batavia. Upon return to the Dutch Republic, the bill could be converted back into cash. ${ }^{69}$ How important this category of income was to the voc in Asia becomes clear from a refusal of inhabitants to sign bills of exchange in 1739, which worsened the Company's shortage of cash immediately. ${ }^{70}$

67 Nederlandsch-Indisch Plakaatboek, 1602-1811. Vol. 5: 1743-1750, vol. 5: 1743-1750 (Batavia: Landsdrukkerij 's Hage: Nijhoff, 1888), 713.

68 Plakaatboek 4, 4: 1709-1743:408-9.

69 Gaastra, "Geld tegen goederen," 256-57; Femme Simon Gaastra, "Private Money for Company Trade. The Role of the Bills of Exchange in Financing the Return Cargoes of the voc.," Itinerario : Bulletin of the Leyden Centre for the History of European Expansion 18, no. 1 (1994): 65-76.

70 Gaastra, Particuliere; G.M., 2004, X 1737-1743:384; Gaastra, "Private Money"; Nierstrasz, In the Shadow of the Company, 163: Unfortunately, Nierstrasz mentioned this, but did not quantitatively specify the maginitude. 
An inverse situation occurred in 1748, when the High Government announced it would refuse bills of exchange drawn in Europe, in order to allow the voc in Amsterdam to ship more money to Asia. ${ }^{71}$ At first sight, this seems an odd policy, since the acceptance of coins in Asia would have resulted in money readily available. But the argument with which the High Government defended its decision is telling: it wished to increase the volume of the circulation in Asia by increasing imports from Europe. So the increase in the total money supply gained precedence over the immediate collection of cash for the High Government.

In order to accurately draw up the request from the Republic, Asian voc officials constantly tried to forecast and balance their future incomes and expenditures. In 1741, 7 million guilders' worth was received from Europe, which sufficed to pay the demanded 4.7 million guilders from the subordinate trading posts and interest over deposits of 300,ooo guilders. The net receipt thus amounted to approximately 2 million guilders, resulting in a total money stock of 3.8 million guilders. This means that the Money Chambers' stock amounted to 1.8 million guilders' worth just before the ships from Europe arrived. ${ }^{72}$ The High Government furthermore stated that if the previous request was not fully paid, the shortfall had to be added to the next request. ${ }^{73}$ Hence, the Batavian voc officials adjusted their monetary requests based on the level of past compliance by the Dutch voc officials with previous requests.

If the amounts of money received proved less than requested, the High Government simply increased the next request to the value of the previous shortfall. It employed this strategy, for instance, in 1745, when it increased the requested sum from 3 million to 3.6 million, because the Amsterdam board had written that they would only supply 2.4 million of the requested 3 million over 1743. Moreover, the High Government deemed the money stock of 3.2 million in 1745 too small to cover the expenses for the Company's purchases. ${ }^{74}$ As shown from the Money Chamber's account, the Asian Company officials had every reason to ask for more money, if only to cover the deficits incurred through Money Chamber. Shortages of cash in Batavia caused problems for trade elsewhere in Asia; pepper in Banten, Palembang and Borneo was purchased on credit and the Bengal office had to borrow locally. Therefore, the

71 Gaastra, "Geld tegen goederen," 256-57; Generale Missiven van Gouverneurs-Generaal En Raden Aan Heren XVII Der Verenigde Oostindische Compagnie, vol. XI 1743-1750, Rijks Geschiedkundige Publicatiën : Grote Serie 232 (Den Haag: Instituut voor Nederlandse Geschiedenis, 1997), 638.

72 G.M., 2004, X 1737-1743:745.

73 G.M., 1997, XI 1743-1750:638.

74 G.M., XI 1743-1750:214. 
High Government urged the Gentlemen XVII to fulfil the demands, including those from previous years amounting to 14 million guilders. ${ }^{75}$

If the local demand for money decreased, the request from the Dutch Republic was reduced as well. The request in 1743 was, for instance, decreased from 5.2 million to 3 million guilders and that for 1757 from 5.8 million to 5.2 million guilders. ${ }^{76}$ By 1758 there was an oversupply of the fractional duiten coins in Java's economy. With reference to further unspecified inconvenience to Java's inhabitants - presumably inflation - the High Government decided to halt the issuance of duiten from the Company's office in June 1757, and no duiten were sent over from the Republic. ${ }^{77}$ The measure had not produced the desired effect by the next April, since the duiten still exchanged at a 15 per cent discount. The company, therefore, decided to repurchase duiten at a 10 per cent discount. ${ }^{78}$ The voc subsequently incurred a loss compared to the nominal value, albeit not as large when compared to market exchange price. From a purely business perspective, it made little sense to incur a loss to diminish the oversupply of fractional coins in circulation.

A few years later, in 1763 , the demand for smaller fractional coins had increased again in the Semarang hinterlands. The High Government was happy to see that the money stock in duiten and shillings had decreased, because of transfers to Java's northeast coast. The issuance of shillings, in particular, was an unexpected success. The susuhunan of Mataram even requested more of this currency. The High Government sent 95,0oo guilders' worth of shillings in response. The decline of fractional coins in stock, however, made the Batavian officials worry that they would possess insufficient quantities to send to the subordinate trading posts. Therefore, they requested more payement from the Dutch Republic. Meanwhile, they stipulated that Batavian bakers pay for wheat in duiten, ${ }^{79}$ which would then raise the stock of duiten again. So, the High Government sometimes limited the request for money-both in total and for specific currencies - and pursued an active policy to manage the local money supply.

There is yet another reason to believe the Asian section of the voc responded sensitively to the local currency requirements, through the Requests of the

\footnotetext{
75 G.M., XI 1743-1750:616-7.

76 G.M., 2007, XIII 1756-1761:162; G.M., 1997, XI 1743-1750:7.

77 Bruijn, Gaastra, and Schöffer, DAS, I: Introductory volume: 223-46; Plakaatboek 7, 7: 1755-1764:256.

78 Plakaatboek 7, 7: 1755-1764:256.

79 H.K.'s Jacob, Generale Missiven van Gouverneurs-Generaal En Raden Aan Heren XVII Der Verenigde Oostindische Compagnie, vol. 14: 1761-1767, Rijks Geschiedkundige Publicatiën Grote Serie 270 (Leiden: Sidestone Press, 2017), 312.
} 
Indies. In 1743 the voc had acquired mintage rights from the sushunan, which they could have used to solve temporary deficits for certain coins types. Yet only in a limited number of years did the voc mint coins locally, and only when European wars hindered regular imports. The first period coincided with the War of the Austrian Succession (1740-1748), the second with the Seven Years' War (1756-1763), the third with the Fourth Anglo-Dutch War (1780-1784) and fourth with the period following the Batavian Revolution of 1795. In total, less than 400,000 guilders' worth was minted between 1743 and $1808 .^{80}$ This is a negligible amount compared to the annual average of 4.7 million guilders' worth of monetary exports from the Netherlands in the eighteenth century. Local mintage was only a rarely used emergency measure, whereas the Requests of the Indies reflected the need for means of exchange to which the VOC in the Netherlands generally responded adequately and dynamically. ${ }^{81}$

\subsubsection{Checking the Requests in Amsterdam}

Formulating a request based upon local demands in Batavia is only the first step in the process to assess whether the voc adapted its shipments of money to local currency preferences. The next issue is how the voc in Amsterdam responded to the requests. Did they accept their Asian counterparts' judgements? We already saw that the Asian voc officials would request more money the next time, if the response did not meet their demand and insufficient funds were sent over. A deviation from the requested amounts may imply a conflicting perception of much money Batavia needed, by the voc in Amsterdam.

The Gentlemen XVII in Amsterdam used a simple yet cunning strategy to evaluate whether the 'Request from the Indies' was justified. It compared the requests received from the High Government with the alterations of the money stock held at the Grand Money Chamber in Batavia. ${ }^{82}$ In 1730 the Gentlemen XVII had imposed a regulation that a statement be prepared once a year and, a year later, that a monthly statement of the funds remaining be included in the resolutions of the High Government. ${ }^{83}$ This method allowed them to moni-

8o Feenstra, "Dutch Coins," 161; Gaastra, Geschiedenis, 166-67; Cornelis Scholten, De Munten van de Nederlandsche Gebiedsdeelen Overzee, 1601-1948 (Amsterdam: Schulman, 1951), 56-65.

81 As to why imports were preferred over local production, may have had to do with the high quality and efficient production of the Dutch minting houses. Albert A.J. Scheffers, Om de kwaliteit van het geld: het toezicht op de muntproductie in de Republiek en de voorziening van kleingeld in Holland en West-Friesland in de 18de eeuw ([Unpublished PhD thesis Leiden Univerity, 2013).

82 NA, Collectie Hope, inv.nr. 105, passim.

83 Plakaatboek 4, 4: 1709-1743:273, 287. 
tor the actual use of the money in Asia and provided them with a device to check the actions from the High Government in Batavia.

It is clear that the Gentlemen XVII depended on statements from Batavia, making this process vulnerable to manipulation by the High Government. On the other hand, inconsistent reporting could raise the Gentlemen XvII's suspicion, as happened in 1757: the debt reported in the request amounted to 2.3 million guilders, whereas a memo attached to the same request indicated the amount of 1.5 million guilders. The Gentlemen XVII voiced their displeasure about the inaccuracy and demanded that the money sent over was to be used exclusively to redeem the debt. ${ }^{84}$

Such suspicions seem to have led to another attempt to increase control by the Amsterdam board. In 1763 , the Gentlemen XVII noted that it had not received a statement of the funds remaining in the Ternate trading post over 1759/176o. The fact that the Gentlemen XVII evidently expected such a statement implies that some offices were to send these overviews directly to the Dutch Republic - presumably the larger trading posts-and others to send a trifold statement to Batavia, which would then forward it. ${ }^{85}$ In this way the Gentlemen XVII bypassed Batavia and enforced consistency in the bookkeeping.

There seems to have been a correlation between the requested sums of money and bullion and the amount and denominations actually sent over from the Dutch Republic, but the correlation was not a simple one. Examination of the two aforementioned requests from 1779 and 1781 (cf. Tables 2 and 3 above) suggests that —at least by the later eighteenth century — the compliance was high and exceeded the request for certain types of money. The analysis of the Company's correspondence shows that a number of sources for money played a part in drawing up the request, from the evaluation in the Dutch Republic, to borrowing in Asia and restricting the use of bills of exchange.

It is nevertheless clear that the Company was forced to comply with the demands of the market and was far from imposing its policy directly on Java's economy. This is most obvious from the greater reluctance to acceptance of the duiten than dubbeltjes. The absence of duiten imports in some years was thus caused by a lack of demand, to which the voc in Asia responded accurately. By repurchasing the duiten coins at an unfavourable rate in the $175 \mathrm{os}$, the Voc gave priority to its role as a sovereign, rather than acting as a profit seeking enterprise. Likewise, the Company in Asia gave precedence to an orderly money circulation by requesting fractional coins instead of the more

$84 \quad$ G.M., 2007, XIII 1756-1761:162.

85 Jacob, GMXIV, 14: 1761-1767:317. 


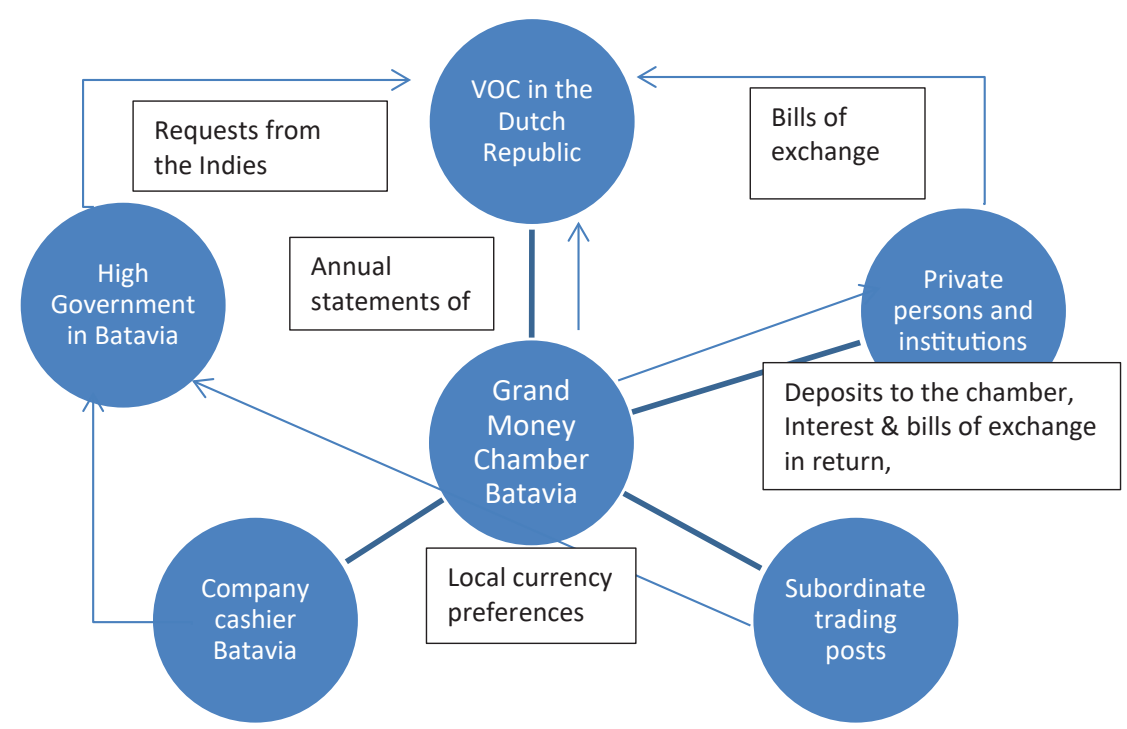

FIGURE 2 Diagram of the voc's information and currency flows

profitable ducats. In both instances, the Companny prioritised the maintenance of a sound money supply for its subjects over profits.

\section{4}

\section{Currency Preferences and Commodity Production}

A sound money supply was clearly not the main reason for the Asian branch of the voc to request specific currencies: such requests in fact related to specific transactions in the Company's trading activities. For instance, the local office in Banten needed Reals to pay for the Company's pepper purchases. This reflected the preference not of the sultan himself, but rather of his subjects in the Lampong region -in Sumatra, which was also under the sultan's control-where the alternative ducatoon coins were not accepted. The local officials expressed their concern about the lack of Reals, and warned that if the Gentlemen XVII in Amsterdam did not send this currency, the pepper could not be purchased. ${ }^{86}$ So, even if the voc did not deal directly with local producers, their currency preferences translated into the demands made to the Amsterdam directors through the local elites. 
In the first part of the seventeenth century, the High Government wished to stay away from petty trade in the local market. ${ }^{87}$ By the end of the century, they had nevertheless become involved with the local markets. The voc-related sectors of Java's economy grew, including the demand for rice and timber for local use. ${ }^{88}$ The increased demand for export products stimulated the local economy, causing a higher number of transactions, which increased the need for good-quality coins. ${ }^{89}$ Such payments were not necessarily conducted in large coins normally used in wholesale trade, and small-denomination coins were sometimes used instead. ${ }^{90} \mathrm{~A}$ nice glance into the relation between currency and export products on Java comes from a description of a transport from the Cirebon coast; in late $173^{2}$ the local resident requested small change, ducatoons and rupias from Batavia in exchange for rice, coffee and timber. ${ }^{91}$ The relationship between these specifically requested currencies and these three commodities is illustrative for the voc's functioning in eighteenth-century Java, as will be detailed below.

Batavia depended heavily on the import of rice from Java's northeast coast. Its immediate hinterlands produced too little to provide for its inhabitants. The Company's involvement in Mataram's political affairs cannot be separated from this dependence. ${ }^{92}$ Local elites played an intermediate role in connecting the voc to the ordinary Javanese rice producers, as we can see in a statement of members of Madura's ruling elite. They declared in 1739 that under the voc's protection they enjoyed peace, and were well remunerated for the products they delivered to the Company. ${ }^{93}$ The demand for commodities was determined not just by the Company's own consumer needs, but also by the sales prices elsewhere around the globe, as in the case of the cash crops coffee and sugar. This section aims to demonstrate that the voc in the various cases responded to specific local currency preferences to acquire the desired commodities.

My line of argument here contrasts with Els Jacobs' view that even though the voc's monopolies were not watertight, their policies damaged overall

87 Blussé, Strange Company, 71: the reference concerns 1639, while Blussé suggests that this was the general policy, at least in this period.

88 Peter Boomgaard, "Why Work for Wages? Free Labour in Java, 160o-19oo," Economic and Social History in the Netherlands 2 (1990): 37-56.

89 Feenstra, "Dutch Coins" 182.

9o Lucassen, "Introduction"; Jan Lucassen, "Deep Monetisation: The Case of the Netherlands 1200-1940," TSEG/ Low Countries Journal of Social and Economic History 11, no. 3 (September 15, 2014): 73-122.

91 G.M., 1988, IX 1729-1737: 455 .

92 Nagtegaal, Hollandse Tïger, 173; Van Niel, Java's Northeast Coast 1740-1840, 123.

93 Nagtegaal, Hollandse Tijger, 107. 
economic development in Java. ${ }^{94}$ Monopolies are disruptive for free-market operations. The question is whether the voc's operations actually damaged Java's local economy. Moreover, keeping an eye on the public interest, as happened with regard to the money supply, would contradict such a strong claim as made by Jacobs. To determine what policy the voc pursued and what the effects were, the current section scrutinises the Company's economic behaviour on Java, looking at to what extent monopolies existed and functioned for the acquisition of the desired commodities.

The monopolies exploited by the voc form an outstanding example of the dualistic character of the organisation; political power and economic interest were entirely interwoven. The Company's monopolistic system was, however, a bit more complex than the term suggests at first sight. Historiography distinguishes three types of monopoly in the voc's operations: (1) trade between Asia and the Ducht Republic, (2) Dutch trade between voc trading posts within Asia and (3) on certain commodities, either due to territorial control by the Company itself or exclusive agreements with Asian rulers. In Java, only the third type of monopoly existed, in both manifestations. ${ }^{95}$

This section concentrates on the monopolistic trade in two commodities, rice and coffee. For rice, the direct interaction with local producers increased during the eighteenth century, although the deliveries through the Javanese elites remained in place. Coffee was a different case, as it was not 'native' to Java, but was introduced by the voc. At first, the coffee plants were handed out to the local elites. Consequently, the demands of the local population showed indirectly at first, through local intermediaries such as the coastal gentry and Chinese traders. ${ }^{96}$ Over the course of the eighteenth century, the Company became more directly involved in the production by local planters and thus had increasingly to respond to demands made by Javanese population directly.

\subsection{Rice}

Rice had long been Java's major export product, at least since the sixteenth century, but probably since much earlier. ${ }^{97}$ When the Dutch arrived at the end

\footnotetext{
94 Jacobs, Koopman in Azië, 209-13.

95 Arthur Weststeijn, "The voc as a Company-State: Debating Seventeenth-Century Dutch Colonial Expansion," Itinerario 38, no. o1 (2014): 15-6; de Zwart, "Globalization in the Early Modern Era, p. 536.

96 Nagtegaal, Hollandse Tijger, 180-89; Kwee, The Political Economy of Java's Northeast Coast, c. 1740-180o.

97 Paul Alexander and Peter Boomgaard, In the Shadow of Agriculture: Non-Farm Activities in the Javanese Economy, Past and Present (Amsterdam: Royal Tropical Institute, 1991), 16; Nagtegaal, Hollandse Tïger, 144.
} 
of the sixteenth century, they discovered that rice could be purchased only with pici-coins. ${ }^{98}$ Direct purchase from rice producers was difficult, since the Javanese state held a monopoly exercised by the local gentry, who acted as intermediaries between the Company and the peasants. ${ }^{99}$ This indirect nature of the trade might obscure the eventual means of payment received and demanded by the Javanese.

Indirectly, however, the locals' currency preferences may be inferred. There are, for instance, indications that the Dutch silver dubbeltjes were increasingly used for purchases of rice from the local Javanese gentry, by the turn of the eighteenth century. The preference for dubbeltjes was a relatively recent phenomenon that had only gradually evolved after 1677 , when the voc decided to use these coins to pay for its purchases. ${ }^{100}$ In 1724, voc ships bound for the Moluccas could not ship all the rice from Tegal on Java's northeast coast, because the voc lacked sufficient quantities of dubbeltjes, which the Javanese demanded as means of payment. ${ }^{101}$ A short supply of rice for exports around Semarang, in 1729 , could be resolved only by a Chinese middleman, who advanced a great sum in cash, provided that it was paid in dubbeltjes. ${ }^{102}$ An adjustment in the exchange rate for fractional coins led to the refusal of dubbeltjes as payment in 1736. The Batavian government did not understand the sushunan's opposition, as the voc would accept the fractional coins at the same rate as it issued them. Nevertheless, it would pay Reals to those who preferred them over the dubbeltjes. In anticipation, the voc had sent 15, ooo Reals to the Javanese officials in Semarang. ${ }^{103}$ In 1742 , a lack of dubbeltjes in Semarang increased the rice price. The voc offered a payment in duiten instead, which was accompanied with the promise to exchange them for dubbeltjes once an adequate supply was restored. ${ }^{104}$ By 1754, the voc provided an advance for the rice harvest in dubbeltjes to Javanese northeast coast gentry. The Company stipulated that this advance was to be paid to the local peasants. At the same time the voc officials

98 Nagtegaal, Hollandse Tijger, 185.

99 Peter Boomgaard, Children of the Colonial State: Population Growth and Economic Development in Java, 1795-1880 (Amsterdam, 1987), 115; Nagtegaal, Hollandse Tijger, 145-8.

100 Nagtegaal, Hollandse Tijger, 187.

101 G.M., 1979, VII 1713-1725:702.

102 G.M., 1988, IX 1729-1737:59.

103 G.M., 1997, XI 1743-1750:694.

104 G.M., 2004, X 1737-1743:971; To give an impression of purchasing power and rice prices, a wage labourer earned between 25 to 30 duiten per day and a daily portion of rice cost 3 to 4 duiten: Feenstra, "Dutch Coins." 
along Java's northeast coast urgently bade the Batavia office to fulfil their submitted request (eisch) for dubbeltjes to pay for future rice purchases. ${ }^{105}$

Whether the voc could obtain sufficient quantities of rice depended of course not only on the availability of dubbeltjes, but also on production. After the Peace of Gyanti was concluded in 1755, the war-stricken rice cultivation got the attention of the High Government. The goal was to quickly restore rice production. This was hampered due to the lack of buffalos and other necessities for rice cultivation. In order to restore production, the voc used a monetary incentive. It doubled the purchase price from 24 guilders per koyang to 48 guilders. ${ }^{106}$ No reductions of this price were allowed. Anyone who had not received the full payment, or was forced to give a rebate to someone else, was allowed to file a complaint in Semarang. If these complaints were justified, justice would be done in such a manner that it would "scare off [others] from harming commoners". ${ }^{107}$ This threat to punish anyone reducing the higher price was clearly aimed at the local elites and potentially corrupt voc servants; the High Government wanted to make sure the impoverished peasants benefitted.

Similarly, De Zwart and Van Zanden demonstrate that the voc often lost money on the sale of rice in Batavia. ${ }^{108}$ They explain this phenomenon by arguing that the Company was more interested in feeding its employees than making a profit from rice. Their finding chimes with the public condemnation of the private sale of rice in Batavia in 1714 at market prices, instead of the lower official prices set by the High Government. They did not tolerate this form of 'usury' at the expense of the poorer part of the population. ${ }^{109}$ The voc thus protected the weaker, including Javanese rice peasants, employees or poorer citizens in Batavia, by offering generous prices and shielding them from large fluctuations of rice prices. ${ }^{110}$

105 Generale Missiven van Gouverneurs-Generaal En Raden Aan Heren XVII Der Verenigde Oostindische Compagnie, vol. XII 1750-1755, Rijks Geschiedkundige Publicatiën: Grote Serie 257 (Den Haag: Instituut voor Nederlandse Geschiedenis, 2007), 399.

106 At the time, a koyang equalled 3,500 £-Troy [Dutch: Pond Trooisch] was about o,494 'kilogram', so a koyang equalled approximately 1,729 kilograms: Marc Kooijmans and Judith Ellen Oosterling, VOC-Glossarium: Verklaringen van Termen, Verzameld Uit de Rijks Geschiedkundige Publicatiën, Die Betrekking Hebben Op de Verenigde Oost-Indische Compagnie (Den Haag: Instituut voor Nederlandse Geschiedenis, 200o).

107 Plakaatboek 7, 7: 1755-1764:110-2.

108 De Zwart and Van Zanden, "Labor."

109 Plakaatboek 4, 4: 1709-1743:46-8.

110 This policy rather resembles a form of 'moral economic' behaviour as put forward by James Scott and E.P. Thompson, rather than pure capitalist behavirour: Marc Edelman, "Bringing the Moral Economy Back In ... to the Study of 21st-Century Transnational Peasant Movements." American Anthropologist 107, (2005), 331-3. 
Rice prices became less volatile and tended to decrease after the lasting peace of 1755 was concluded. ${ }^{111}$ Nagtegaal and, De Zwart and Van Zanden suggest that the Company's increasing economic involvement may have caused more efficient use of land and labour, and living standards may have improved between 1740 and 1790.112 This is consistent with the observations of a contemporary, who noticed an increase in cultivated rice lands, which suggests that the voc's purpose to stimulate rice production succeeded. ${ }^{113}$ The absence of inflation in the second half of the eighteenth century further suggests that increased monetisation may have stimulated rice production. ${ }^{114}$

The Company was nevertheless far from controlling the rice market. It remained dependent on market operations to acquire sufficient quantities of rice. An inadequate supply of duiten during the late eighteenth century complicated rice purchases, because the local people now preferred these coins as means of payment. Consequently, the Company's rice purchasers first had to acquire the duiten at a premium - for the scarcity of duiten increased their exchange rate-and then purchase the rice relatively dear. ${ }^{115}$ This shows the limited control of the Company over the rice market vis-á-vis the bargaining power of the local rice producers, who strikingly did not simply demanded a higher price but, instead, required use of the duit as a chosen means of exchange.

Meanwhile, it was not only the production of rice that increased during the second half of the eighteenth century, but also its consumption. This was the case in the coastal area as well as in the Mataram principalities. The common man increasingly ate rice instead of root crops, which is seen as an indication of increased prosperity that resulted from the lasting peace after $1755 .{ }^{116}$

\subsection{Coffee}

Coffee was the other agrarian commodity that received noticeable attention from the VOC in the early eighteenth century. European demand, production in other parts of the world and local relations all played a part in the development of coffe production in Java - a process which can be divided into three periods.

\footnotetext{
111 De Zwart and Van Zanden, "Labor."

112 Nagtegaal, Hollandse Tijger, 197; De Zwart and Van Zanden, "Labor," 228, 230.

113 De Zwart and Van Zanden, "Labor," 226; Van Niel, Java's Northeast Coast 1740-1840, 130.

114 Pim de Zwart, Globalization and the Colonial Origins of the Great Divergence. Intercontinental Trade and Living Standards in the Dutch East India Company's Commercial Empire, c. 1600-1800 [unpublished PhD thesis Utrecht University] (2015), 117, 193; Feenstra, "Dutch Coins."

115 Van Niel, Java's Northeast Coast 1740-1840, 130-1.

116 Van Niel, 131.
} 
The first period began with a boost in coffee consumption in Europe in the 169os. Until then Yemen had been the only commercial coffee producer in the world. Difficulties with the purchase of coffee there incited the voc to experiment with coffee cultivation in Java. ${ }^{117}$ Although the Company handed out the first coffee trees to the Javanese gentry in 1707, coffee production really boomed after Priangan's ${ }^{118}$ peasantry also began to cultivate this not so labour-intensive side-crop on their own plots as well. ${ }^{119}$ Within two decades Java's coffee production surpassed Yemen's, thereby giving the voc control over $50 \%$ to $75 \%$ of the global coffee production. ${ }^{120}$ To fully benefit from the success, the voc announced a monopoly on the export of coffee, in $1723 .{ }^{121}$ By offering high and fixed prices, the voc persuaded the Javanese to cultivate coffee and shielded them from price fluctuations on the world market. The price mechanism to encourage coffee production worked so well that it resulted in shortages of labourers and cash. ${ }^{122}$

The first of these problems was solved by migrant labour, ${ }^{123}$ the second by offering different means of payments. The voc proposed in 1723 to pay a quarter of the purchasing price in cloth. It stipulated that the cloth was to be of sorts "as desired by the coffee planters." ${ }^{124} \mathrm{~A}$ smuggling prohibition a decade later implies that the cloth must have been in high demand in Java and that illegal imports harmed the Company's interests. ${ }^{25}$ By making a profit on the cloth, the Company aimed to save cash the voc offered cloth as commodity money and thus make the coffee purchase more bearable. ${ }^{126}$

The second period began when the voc in Amsterdam and Batavia began to fear overproduction, in the late 1720 ; it tried to limit production and reduced the purchasing prices dramatically. ${ }^{127}$ Caribbean coffee flooded the European market from the $173 \mathrm{OS}$, causing a downwards price movement. ${ }^{128}$

\footnotetext{
117 Jacobs, Koopman in Azië, 197-202.

118 Mountain area directly to the south of Batavia.

119 Jacobs, Koopman in Azië, 197-208; Knaap, "Coffee for Cash," 37, 44-45; Plakaatboek 4, 4: 1709-1743:159-61.

120 Knaap, "Coffee for Cash," 34, 40.

121 Plakaatboek 4, 4: 1709-1743:159-61.

122 Knaap, “Coffee for Cash," 34, 43, 44-6.

123 Knaap, 43, 45-46.

124 Plakaatboek 4, 4: 1709-1743:180; the edict reads in Dutch: "als 'na de begeerte' der koffijplanters."

125 Plakaatboek 4, 4: 1709-1743:316.

126 The Voc was familiar with this type of payment, as it had used it on other occasions and in other locations before: Nagtegaal, Hollandse Tijger, 182-84; Gerrit J. Knaap, Kruidnagelen en Christenen d. Verenigde Oost-Indische Compagnie en d. bevolking van Ambon 1656-1696 (Dordrecht: Foris Publ., 1987).

127 Jacobs, Koopman in Azië, 203-4; Knaap, "Coffee for Cash," 41.

128 Jacobs, Koopman in Azië, 201-4.
} 
The Company now restricted coffee cultivation to areas closest to Batavia, in Cirebon and Priangan. To this end it entered into an agreement with the susuhunan of Mataram in 1733 , to destroy all coffee trees in his realm. ${ }^{129}$ Five years later, in 1738, the Company decreed the destruction of coffee plants in Cirebon and Priangan as well. At the same time, it stipulated that payments would henceforth be transacted half in cash and half in 4.5\%-bonds, due to a lack of money. ${ }^{130}$ The currency that the Company sought to save for this purpose was presumably the duiten. In 1733, the voc had supplied the local elites with this currency for the specific purpose of purchasing coffee and other commodities from the Priangan region. ${ }^{131}$ The policy of discouragement caused migrant labourers to return home. ${ }^{132}$ Priangan peasants, however, continued to cultivate coffee. ${ }^{133}$ Java's total coffee production nevertheless dropped. ${ }^{134}$

The payment in the form of bonds especially struck the smallest peasant cultivators in the Cirebon region, as Company servants noticed a year after introducing the practice, in 1739. The High Government deemed this means of payment unfit for this group. Therefore, it reversed the 1738 decision by paying for coffee purchases entirely in cash again. At the same time, it sought to incentivise diversification of production, by promising a 100-rixdollar bonus for the first one to harvest 1,00o pikols of pepper instead. ${ }^{135}$ By the end of 1739, all bonds to the coffee producers had been reimbursed. ${ }^{136}$ So, the voc clearly adjusted the means of payments to the intended users, in this case the small coffee cultivators, despite being constrained by inadequate supplies of cash.

During the third phase, from the 176 os onwards, the voc relaxed the conditions under which coffee had to be delivered. This restored the production to 1720 levels. ${ }^{137}$ In 1765 , the Gentlemen XVII ordered that the purchasing price of coffee had to be lowered by a rixdollar per pikol. This, however, was not to be at the expense of the local producers in Cirebon, while any form of coercion was specifically ruled out, too. ${ }^{138}$ This could only mean that a lower margin was left for intermediaries, such as the local elite or Chinese middlemen. In

\footnotetext{
129 Nagtegaal, Hollandse Tijger, 181; Van Niel, Java's Northeast Coast 1740-1840, 170-1.

130 Plakaatboek 4, 4: 1709-1743:434.

131 Plakaatboek 4, 4: 1709-1743:348; another part of the same decree explicitly mentions coffee as a specific commodity from the region.

132 Knaap, "Coffee for Cash," 43.

133 Plakaatboek 4, 4: 1709-1743:449.

134 Jan Breman, Koloniaal profijt van onvrije arbeid: het Preanger stelsel van gedwongen koffieteelt op Java, 1720-1870 (Amsterdam: Amsterdam University Press, 2010), 83, 255.

135 Plakaatboek 4, 4: 1709-1743:448-9.

136 G.M., 2004, X 1737-1743:393.

137 Jacobs, Koopman in Azië, 206-8.

138 Jacob, GMXIV, 14: 1761-1767:910.
} 
return for coffee and other commodities, the voc sent money to Cirebon, in the mid-1770s, consisting for a large part-approximately 950,00o pieces annually—of duiten. ${ }^{139}$ From 1778 , voc officials were appointed to personally monitor that the coffee planters received an immediate and full payment for their deliveries to the Javanese noblemen (regenten). The Fourth Anglo-Dutch War (1780-1784) prevented a strict execution of the policy, as the Company suffered during this period from a shoratage of cash. After the war, coffee was seen as one of the trades that could enable the Company's recovery, which led to further stimulation of the cultivation. ${ }^{140}$

Insufficient quantities of cash could hamper coffee cultivation; without a monetary reward the Javanese lacked the incentive to produce the crop. Such was the case in early July 1785 . A first step to meet the demand for cash was to provide coffee producers with a cash advance, specifying that at least part thereof was to consist of copper duiten. ${ }^{141}$ That this was not enough becomes evident from a report that the examiner for inland affairs, Leendert Rollf, submitted to the High Government a few weeks later. He stated that a further lack of cash would lead to decline in the coffee cultivation in the Java mountain region. The High Government was convinced by his analysis and deemed a decline of coffee production problematic as well. Not only had it to deal with this problem, but it was also constrained by the limited amounts of cash in the Company's coffers. Eventually, the High Government allowed Rollf to issue paper money with a 6\% discount rate, so that he might have sufficient cash to to purchase coffee from the local producers. ${ }^{142}$ Just as with sugar, so too local producers' preference was for cash in smaller currencies, rather than letters of credit. ${ }^{143}$ This thus forced the Company to adopt the indirect solution of first selling credit paper at a loss to obtain cash needed to maintain coffee production.

The demand for Javanese coffee was further fostered by decreasing supplies from the Caribbean in the early 179os, due to the uprising of Toussaint Louverture in nowadays Haiti. ${ }^{144}$ How these developments on the global coffee market eventually affected the common man's daily transactions is hard

139 Gerrit J. Knaap, Shallow Waters, Rising Tide: Shipping and Trade in Java around 1775, Verhandelingen van Het Koninklijk Instituut Voor Taal-, Land- En Volkenkunde 172 (Leiden: KITLV Press, 1996), 102.

140 Jacobs, Koopman in Azië, 206-7.

141 Nederlandsch-Indisch Plakaatboek, 1602-1811. Vol. 10: 1776-1787, vol. 10: 1776-1787 (Batavia: Landsdrukkerij 's Hage: Nijhoff, 1892), 790.

142 This transaction suggests that the peasants in the mountain region did not accept the 'papers of credit' and that he first had to issue that in Batavia: Plakaatboek 10, 10: 17761787:792-3: the amount he was allowed to issue amounted to 30,000 to 40,0oo rixdollars.

143 About the sugar, letters of credit and small cash: Plakaatboek 10, 10: 1776-1787:598, 728-9.

144 Jacobs, Koopman in Azië, 206-7. 
to observe for most of the eighteenth century. This is partly due to the control of the local elites over the coffee production and the distribution of the revenues. ${ }^{145}$ For the early nineteenth century, there are some indications that duiten were the preferred means for coffee purchases coffee. In 1803, a shipment of duiten was allocated to purchase coffee. ${ }^{146}$ In 1807 , we also hear about the importance of sufficient quantities of duiten to purchase coffee from commoners in Priangan. ${ }^{147}$ The duiten had become the general means of payment for coffee, at least from the 1770s, when their quantities had been significantly increased and perhaps even as early as the 1730s. Yet when their quantities fell short, coffee production came to a halt, illustrating the importance of specific types of cash for the voc to obtain the desired products.

\section{Conclusion}

By reconstructing the chain of demand, from ordinary Javanese, through the local elites, the Asian voc officials and Batavia's High Government to the Board of Directors in Amsterdam, this paper demonstrates that the Javanese's currency preferences were visible in the exports from Europe. With the voc's increasing involvement in Javanese society from the 168os, the demand for smaller-denomination coins increased as well.

The voc was not in a position to impose its will, let alone subjugate the economy, as other studies have already showed. The voc's inability to end the recurrent warfare, in spite of its ambitions, illustrates this relative weak position. When peace was finally established after 1755, Java's economy grew. Studies by Nagtegaal and De Zwart and Van Zanden have even tentatively suggested that it is possible that the voc's involvement had positive consequences. This paper demonstrates that with regard to the money supply, considerations of state prevailed over purely business interests. By offering fixed and often high purchasing prices, the voc functioned as a buffer between the local producers and the global market, and protected them against price fluctuations. Rice producers, the Batavian poor and Company employees were similarly protected against either too high or too low rice prices. This allowed the Javanese to benefit from the Company's global connections, while the voc bore part of

\footnotetext{
145 Knaap, "Coffee for Cash," 45.

146 Elisabeth Susanna van Eyck van Heslinga, Van compagnie naar koopvaardij: de scheepvaartverbinding van de Bataafse Republiek met de koloniën in Azië 1795-1806, Hollandse historische reeks 9 (Amsterdam: De Bataafsche Leeuw, 1988), 700.

147 Frédéric Jules Pierre Moquette, De Munten van Nederlandsch-Indië (Batavia: Albrecht, 1909), 273 .
} 
the risk of the price fluctuations. As such, the voc did not aim to plunder the Javanese economy, but rather acted a as morally responsible ruler.

The analysis of voc's monetary flows shows that it responded to specific monetary needs to let its Asian operations function as smoothly as possible. The money wished for in the Requests from the Indies correspond fairly well to those that the company shipped to Asia. The export figures thus form a relatively representative indication of the needs of the voc in Asia. The currency supply was demand-driven.

Those needs shifted throughout the late seventeenth and eighteenth centuries: an increasing involvement with Java's growing economy resulted in different needs for the voc in Batavia. The shifting balance in its role on Java - from merchant to state-was visible in the voc's increasing demand for lower-denomination cash coins. The voc's sources thus give a voice to the indigenous population, even when we lack indigenous sources.

The voc's changing role intensified the contact the company's contact with the local producers. As a ruler the voc had to respond to their needs. It could not just enforce the acceptance of all means of payments. Insofar as we can determine, the rice producers demanded certain types of money: by the late sixteenth century picis, until the mid-eighteenth century dubbeltjes and thereafter duiten. The payment for coffee followed a similar pattern of the local preference for certain types of coins. Insufficient quantities of those currencies subsequently led to purchasing problems.

Consequently, the voc's behaviour in monetary affairs is best understood as a response to local demand. The growing Dutch involvement did not result in an outright repression of Java's population, a subjugation of the existing powerholders or even the disruption of the economy. Instead, the Dutch presence appears to have had certain benefits, not because of its power, but because of its lack thereof. This forced the Company to take the local powerholders and their interests into account and comply with their preferences.

\section{Acknowledgments}

The author wishes to thank Ulbe Bosma, Joost Schokkenbroek, Christiaan van Bochove, Remco Raben, the participants in the Wageningen Rural History seminar and the AAS Workshop "New Frontiers in Asian Economic History" in Lansing, Michigan, and the "Multiple payment systems in globalizing economies" workshop in Osaka and session of the same name at the Boston WEHC 2018 and the anonymous referee for their valuable feedback on earlier drafts of this paper. 


\section{Bibliography}

Acemoglu, Daron and James A. Robinson. 2012. Why Nations Fail: The Origins of Power, Prosperity, and Poverty. London etc.: Profile Books,.

Alexander, Paul and Peter Boomgaard. 1991. In the Shadow of Agriculture: Non-Farm Activities in the Javanese Economy, Past and Present. Amsterdam: Royal Tropical Institute.

Atsushi, Ota. 2006. TANAP Monographs on the History of the Asian-European Interaction, vol 3. Changes of Regime and Social Dynamics in West Java: Society, State and the Outer World of Banten, 1750-1830. Leiden etc.: Brill.

Blussé, Johan Leonard. 1986. Strange Company: Chinese Settlers, Mestizo Women and the Dutch in VOC Batavia. [Leiden].

Boomgaard, Peter. 1987. Children of the Colonial State: Population Growth and Economic Development in Java, 1795-1880. Vrije Universiteit Amsterdam: PhD thesis.

Boomgaard, Peter. 1987. Morbidity and Mortality in Java, 1820-1880: Changing Patterns of Disease and Death. In Death and Disease in Southeast Asia: Explorations in Social, Medical and Demographic History, ed. Norman G. Owen. Singapore etc.: Oxford University Press, 48-69.

Boomgaard, Peter. 1990. Why Work for Wages? Free Labour in Java, 1600-19oo. Economic and Social History in the Netherlands 2: 37-56.

Boomgaard, Peter. 2009. Labour, Land, and Capital Markets in Early Modern Southeast Asia from the Fifteenth to the Nineteenth Century. Continuity and Change: AJournal of Social Structure, Law and Demography in Past Societies, 1: 55-78.

Boomgaard, Peter and A.J. Gooszen. Changing Economy in Indonesia vol. 11. Population Trends 1795-1942. Amsterdam: Royal Tropical Institute (KIT), 1991.

Bosma, Ulbe. 2013. Why Europe Grew Rich and Asia Did Not. International Review of Social History, 1. 119-30.

Breman, Jan. 2010. Koloniaal profijt van onvrije arbeid: het Preanger stelsel van gedwongen koffieteelt op Java, 1720-1870. Amsterdam: Amsterdam University Press.

Broadberry, Stephen and Pierre van der Eng. 2010. Historical Perspectives on Asian Economic Growth and Development. Explorations in Economic History, 3. 26o-4.

Bruijn, J.R., F.S. Gaastra, and I. Schöffer, eds. 1987. Dutch-Asiatic Shipping in the 17th and 18th Centuries. Vol. I: Introductory Volume. Vol. I: Introductory volume. The Hague: Nijhoff.

Clulow, Adam. 2014. The Company and the Shogun: The Dutch Encounter with Tokugawa Japan. Columbia Studies in International and Global History. New York: Columbia University Press.

De Vries, Jan. 2010. The Limits of Globalization in the Early Modern World. The Economic History Review 63. 710-34. 
De Zwart, Pim and Jan Luiten Van Zanden. 2015. Labor, Wages, and Living Standards in Java, 1680-1914. European Review of Economic History 19.

Edelman, Marc. 2005. Bringing the Moral Economy Back In ... to the Study of 21st-Century Transnational Peasant Movements. American Anthropologist 107, 331-45.

Feenstra, Alberto. 2014. Dutch Coins for Asian Growth. VOC-Duiten to Assess Java's Deep Monetisation and Economic Growth, 1724-180o. Tijdschrift Voor Sociale En Economische Geschiedenis 11. 123-54.

Flynn, Dennis Owen and Arturo Giraldez. 2002. Cycles of Silver: Global Economic Unity through the Mid-Eighteenth Century. Journal of World History 13. 391-427.

Gaastra, Femme S. 1976. De Verenigde Oost-Indische Compagnie in de zeventiende en achttiende eeuw: de groei van een bedrijf. Geld tegen goederen. Een structurele verandering in het Nederlands-Aziatisch handelsverkeer. Bijdragen en mededelingen betreffende de geschiedenis der Nederlanden 91. 249-72.

Gaastra, Femme S. 1994. Private Money for Company Trade. The Role of the Bills of Exchange in Financing the Return Cargoes of the VOC. Itinerario: Bulletin of the Leyden Centre for the History of European Expansion 18,: 65-76.

Gaastra, Femme S. 2002. Van Gelder-lezingen vol. 1. Particuliere geldstromen binnen het VOC-bedrijf 1640-1795. Leiden: Rijksmuseum Het Koninklijk Penningkabinet.

Gaastra, Femme S. 2007. De geschiedenis van de VOC. Zutphen: Walburg Pers, 2007.

Gelderblom, Oscar, Abe de Jong, and Joost Jonker. 2013. The Formative Years of the Modern Corporation: The Dutch East India Company VOC, 16o2-1623. The Journal of Economic History 73: 1050-76.

1976. Generale Missiven van Gouverneurs-Generaal En Raden Aan Heren XVII Der Verenigde Oostindische Compagnie. Vol. VI 1698-1713. Rijks Geschiedkundige Publicatiën: Grote Serie 159. 's-Gravenhage: Nijhoff.

1979. Generale Missiven van Gouverneurs-Generaal En Raden Aan Heren XVII Der Verenigde Oostindische Compagnie. Vol. VII 1713-1725. Rijks Geschiedkundige Publicatiën: Grote Serie 164. 's-Gravenhage: Nijhoff.

1988. Generale Missiven van Gouverneurs-Generaal En Raden Aan Heren XVII Der Verenigde Oostindische Compagnie. Vol. IX 1729-1737. Rijks Geschiedkundige Publicatiën: Grote Serie 205. 's-Gravenhage: Nijhoff.

1997. Generale Missiven van Gouverneurs-Generaal En Raden Aan Heren XVII Der Verenigde Oostindische Compagnie. Vol. XI 1743-1750. Rijks Geschiedkundige Publicatiën: Grote Serie 232. Den Haag: Instituut voor Nederlandse Geschiedenis. 2004. Generale Missiven van Gouverneurs-Generaal En Raden Aan Heren XVII Der Verenigde Oostindische Compagnie. Vol. x 1737-1743. Rijks Geschiedkundige Publicatiën: Grote Serie 25o. Den Haag: Instituut voor Nederlandse Geschiedenis. 
2007. Generale Missiven van Gouverneurs-Generaal En Raden Aan Heren XVII Der Verenigde Oostindische Compagnie. Vol. XII 1750-1755. Rijks Geschiedkundige Publicatiën: Grote Serie 257. Den Haag: Instituut voor Nederlandse Geschiedenis,. 2007. Generale Missiven van Gouverneurs-Generaal En Raden Aan Heren XVII Der Verenigde Oostindische Compagnie. Vol. XIII 1756-1761. Rijks Geschiedkundige Publicatiën: Grote Serie 258. Den Haag: Instituut voor Nederlandse Geschiedenis,.

Goor, J.van. 2015Jan Pieterszoon Coen, [1587-1629]:koopman-koning in Azië. Amsterdam: Boom.

Hart, Marjolein C. 't. 2014. The Dutch Wars of Independence: Warfare and Commerce in the Netherlands 1570-1680. Modern Wars in Perspective. London: Routledge,.

Heslinga, Elisabeth Susanna van Eyck van. 1988. Van compagnie naar koopvaardij: de scheepvaartverbinding van de Bataafse Republiek met de koloniën in Azië 1795-1806. Amsterdam: De Bataafsche Leeuw.

Jacob, H.K.'s. eds. 2017. Generale Missiven van Gouverneurs-Generaal en raden aan Heren XVII der Verenigde Oostindische Compagnie. Vol. 14:1761-1767. Rijks Geschiedkundige Publicatiën Grote Serie 270. Leiden: Sidestone Press,.

Jacobs, Elisabeth Maria. 2000. Koopman in Azië: de handel van de Verenigde OostIndische Compagnie tijdens de 18de eeuw. Zutphen: Walburg Pers.

Knaap, Gerrit J. 1986. Coffee for Cash. Trading Companies in Asia 1600-1830, HES studies in colonial and non-European history 3: 33-49.

Knaap, Gerrit J. 1987 Kruidnagelen en Christenen d. Verenigde Oost-Indische Compagnie en d. bevolking van Ambon 1656-1696. Dordrecht: Foris Publ.

Knaap, Gerrit J. 1996. Shallow Waters, Rising Tide: Shipping and Trade in Java around 1775. Leiden: KITLV Press.

Kooijmans, Marc and Judith Ellen Oosterling. 200o. VOC-Glossarium: Verklaringen van Termen, Verzameld Uit de Rijks Geschiedkundige Publicatiën, Die Betrekking Hebben Op de Verenigde Oost-Indische Compagnie. Den Haag: Instituut voor Nederlandse Geschiedenis.

Korte, J.P. de. 1984. De Jaarlijkse Financiële Verantwoording in de VOC, Verenigde Oostindische Compagnie. Werken, Uitgegeven Door de Vereeniging Het Nederlandsch Economisch-Historisch Archief 17. Leiden: Nijhoff.

Kwee, Hui Kian. 2006. The Political Economy of Java's Northeast Coast, c. 1740-1800: Elite Synergy. Leiden etc.: Brill.

Kwee, Hui Kian. 2008. How Strangers Became Kings." Indonesia and the Malay World 36: 293-307.

Lieberman, Victor. 1990. Wallerstein's System and the International Context of Early Modern Southeast Asian History. Journal of Asian History. 24: 70-9o.

Lucassen, Jan. 2007. "Introduction: Wages and Currency, 50o BCE-200o CE." In Wages and Currency: Global Comparisons from Antiquity to the Twentieth Century, ed. Jan Lucassen. Bern. Lang: 9-58. 
Lucassen, Jan. 2014. Deep Monetisation: The Case of the Netherlands 1200-1940. TSEG/ Low Countries Journal of Social and Economic History 11: 73-122.

Marcocci, Giuseppe. 2016. Too Much to Rule: States and Empires across the Early Modern World. Journal of Early Modern History 20: 511-25.

Moquette, Frédéric Jules Pierre. 19o9. De Munten van Nederlandsch-Indië. Batavia: Albrecht.

Nagtegaal, Luc W. 1988. Rijden Op Een Hollandse Tijger: De Noordkust van Java En de V.O.C. 1680-1743. Utrecht: Rijksuniversiteit Utrecht.

Nagtegaal, Luc W. 1996. Riding the Dutch Tiger: The Dutch East Indies Company and the Northeast Coast of Java 1680-1743. trans. Beverley R. Jackson Leiden: KITLV Press.

1887. Nederlandsch-Indisch Plakaatboek, 1602-1811. Vol. 4: 1709-1743. Batavia: Landsdrukkerij 's Hage: Nijhoff.

1888. Nederlandsch-Indisch Plakaatboek, 1602-1811. Vol. 5: 1743-1750. Batavia: Landsdrukkerij 's Hage: Nijhoff.

1889. Nederlandsch-Indisch Plakaatboek, 1602-1811. Vol. 6: 1750-1754. Batavia: Landsdrukkerij 's Hage: Nijhoff.

189o. Nederlandsch-Indisch Plakaatboek, 1602-1811. Vol. 7: 1755-1764. Batavia: Landsdrukkerij 's Hage: Nijhoff.

1892. Nederlandsch-Indisch Plakaatboek, 1602-1811. Vol. 10: 1776-1787. Batavia: Landsdrukkerij 's Hage: Nijhoff.

1894. Nederlandsch-Indisch Plakaatboek, 1602-1811. Vol. 12: 1795-1799. Batavia: Landsdrukkerij 's Hage: Nijhoff.

1895. Nederlandsch-Indisch Plakaatboek, 1602-1811. Vol. 13: 1800-1803. Batavia: Landsdrukkerij 's Hage: Nijhoff.

1895. Nederlandsch-Indisch Plakaatboek, 1602-1811. Vol. 14: 1804-1808. Batavia: Landsdrukkerij 's Hage: Nijhoff.

Nierstrasz, Jan Christiaan. 2008. In the Shadow of the Company: The VOC (Dutch East India Company) and Its Servants in the Period of Its Decline (1740-1796). [unpublished PhD thesis Leiden University].

O'Brien, Patrick. 2006. Historiographical Traditions and Modern Imperatives for the Restoration of Global History. Journal of Global History 1: 3-39.

Oostindie, Gert J. 2003. Squaring the Circle-Commemorating the VOC after 400 Years. Bijdragen Tot de Taal-, Land-En Volkenkunde 159: 135-62.

Pol, Arent. 1985. Tot Gerieff van India. Geldexport door de VOC en de Muntproduktie in Nederland, 1720-1740. Jaarboek Voor Munt- En Penningkunde 72: 65-195.

Raben, Remco. 200o. Round about Batavia: Ethnicity and Authority in the Ommelanden, 1650-180o. In Jakarta-Batavia: Socio-Cultural Essays, eds. Kees Grijns and Petrus Jacobus Maria Nas. Leiden: KITLV Press: 93-113.

Reid, A.J.S. 1987. Low Population Growth and Its Causes in Pre-Colonial Southeast Asia. In Death and Disease in Southeast Asia: Explorations in Social, Medical and 
Demographic History, ed. Norman G. Owen. Singapore etc.: Oxford University Press: $33-47$.

Reid, A.J.S. 1993. Southeast Asia in the Age of Commerce, 1450-1680. New Haven, [Conn. etc.]: Yale University Press.

Ricklefs, Merle C. 1974. Jogjakarta under Sultan Mangkubumi, 1749-1792: A History of the Division of Java. London.

Ricklefs, Merle C. 1986. Some Statistical Evidence on Javanese Social, Economic and Demographic History in the Later Seventeenth and Eighteenth Centuries. Modern Asian Studies 20: 1-32.

Ricklefs, Merle C. 1993. War, Culture and Economy in Java, 1677-1726: Asian and European Imperialism in the Early Kartasura Period. London: Allen and Unwin.

Ricklefs, Merle C. 2002. De Verenigde Oost-Indische Compagnie En de Gewelddadige Wereld van Het Vroegmoderne Azië. In De Verenigde Oost-Indische Compagnie : Tussen Oorlog En Diplomatie, eds. Gerrit J. Knaap and Ger Teitler. Leiden: KITLV Uitgeverij: 355-78.

Scheffers, Albert A.J. 2013. Om de kwaliteit van het geld: het toezicht op de muntproductie in de Republiek en de voorziening van kleingeld in Holland en West-Friesland in de 18de eeuw. [unpublished PhD thesis Leiden University].

Scholten, Cornelis. 1951. De munten van de Nederlandsche gebiedsdeelen overzee, 16011948. Amsterdam: Schulman.

Talens, Johan. 1999. Een feodale samenleving in koloniaal vaarwater: Staatsvorming, Koloniale expansie en economische onderontwikkeling in Banten, West-Java, 160o1750. Hilversum: Verloren.

Van Niel, Robert. 1990. Economic and Population Changes in Java, 1750-1850. In Economic and Demographic Development in Rice Producing Societies: Some Aspects of East Asian Economic History, 1500-1900, eds. Yoshihiro Tsubouchi Yoshihiro and Hayami Akira. Tokyo / Leuven: Leuven University Press: 122-41.

Van Niel, Robert. 2005. Java's Northeast Coast 1740-1840:A Study in ColonialEncroachment and Dominance. Leiden: cNws Publications.

Weststeijn, Arthur. 2014 The VOC as a Company-State: Debating Seventeenth-Century Dutch colonial expansion. Itinerario 38: 13-34.

Wolters, Willem G. 2008. Heavy and light money in the Netherlands Indies and the Dutch Republic. Financial History Review 15: 37-54.

Zwart, Pim de. 2015. Globalization and the Colonial Origins of the Great Divergence. Intercontinental Trade and Living Standards in the Dutch East India Company's Commercial Empire, c. 1600-1800. [unpublished PhD thesis Utrecht University].

Zwart, Pim de. 2016. Globalization in the Early Modern Era: New Evidence from the Dutch-Asiatic Trade, c. 16oo-18oo. The Journal of Economic History 76: 520-58. 